Science in Context 30(4), 423-474 (2017). (C) Cambridge University Press 2018. This is an Open Access article, distributed under the terms of the Creative Commons Attribution licence (http:// creativecommons.org/licenses/by/4.0/), which permits unrestricted re-use, distribution, and reproduction in any medium, provided the original work is properly cited.

doi:10.1017/S0269889717000254

\title{
Disciplining Physiological Psychology: Cinematographs as Epistemic Devices in the Work of Henri Bergson and Charles Scott Sherrington
}

\section{Tom Quick}

University of Manchester

quick.tr@gmail.com

\section{Argument}

This paper arrives at a normative position regarding the relevance of Henri Bergson's philosophy to historical enquiry. It does so via experimental historical analysis of the adaptation of cinematographic devices to physiological investigation. Bergson's philosophy accorded well with a mode of physiological psychology in which claims relating to mental and physiological existence interacted. Notably however, cinematograph-centered experimentation by British physiologists including Charles Scott Sherrington, as well as German-trained psychologists such as Hugo Münsterberg and Max Wertheimer, contributed to a cordoning-off of psychological from physiological questioning during the early twentieth century. Bergson invested in a mode of intellectual practice in which psychological claims had direct relevance to the interpretation of physiological nature. The in-part cinematograph-inspired breakdown of this mode had significance for subsequent interpretations of his philosophy. It is suggested that this experimental particularization of Bergson's contentions indicates that any adaptation of his thought for historical enquiry must be disciplinarily specific.

\section{Introduction}

On the 26th of May 1911, the philosopher Henri Bergson gave a lecture to a packed hall at the University of Oxford. Bergson was at the height of his powers: his 1907 Creative Evolution ${ }^{1}$ had catapulted him into the consciousness not only of his native

\footnotetext{
${ }^{1}$ https://cslide.medsci.ox.ac.uk/Items/view/7126 (accessed November 9, 2017). Hyperlinks to a digital writing and database tool ('CSlide': https://cslide.medsci.ox.ac.uk/) have been added to a selection of the items referenced in this paper, as well as to a series of stand-alone discussions of the topics addressed. This approach to the organization and presentation of historical material is intended as a contribution to on-going experimental investigation into the significance of digital tools for historical scholarship. For examples relevant to the history of science, technology and medicine see Nawrotski and Dougherty 2013, and 'The Virtual Laboratory: Essays and Resources on the Experimentalization of Life' (Max Planck Institut für Wissengeschaftsgeschichte, c. 2001-), available at http://vlp.mpiwg-berlin.mpg.de/index_html (accessed 28/10/2016). For recent discussion of
} 
France, but that of a growing international band of followers. He would go on to be recognized as one of the most influential philosophers of the twentieth century. Yet, as Jimena Canales (2015) has recently detailed, not long after this talk Bergson's reputation appeared severely diminished. Merely a decade after his triumphant tour of England, his philosophy was being portrayed as a dangerous form of mysticism out of place in the scientific culture of the twentieth century.

Canales identifies a contentious set of debates between Bergson, his fellow Nobel laureate Albert Einstein, and their respective followers as the immediate cause of the decline in influence of the former. In so doing, her work opens up Bergson's philosophy to historians of science, medicine, and technology. Along with that of Bruno Latour (2005) and Robert Brain (2015, esp. 32-36), it is concerned with it not in relation to the articulation of a normative conception of existence, but rather insofar as it participated in broader intellectual and cultural developments. ${ }^{2}$ Bergson's philosophy was not, as has been all-too-frequently assumed, simply the product of a great mind operating apart from the material and cultural contexts in which it existed. Rather, it drew on and inspired a range of claims and practices relating to the interrogation and apprehension of nature that have recently begun to be re-appraised by humanities and natural science scholars alike (e.g. Mullarky 1999; Lefebvre and White 2012; Mullarky and de Mille 2013; Normandin and Wolfe 2013).

A consideration of Bergson's 1911 talk, however, points to an intriguing element of Canales' analysis that remains unresolved. At Oxford, Bergson was very specific regarding the significance of modern science for philosophy. Casting philosophical endeavor as a dialogue between the Western classical tradition and present-day investigation, he argued for a re-consideration of the former in relation to certain scientific disciplines rather than others:

Let us ... study the ancients, become imbued with their spirit and try to do, as far as possible, what they themselves would be doing were they living among us. Endowed with our knowledge (I do not refer so much to our mathematics and physics, which would perhaps not radically alter their way of thinking, but especially our biology and psychology), they would arrive at very different results from those they obtained. (Bergson [1934] 1946, 153-154)

For the Bergson of 1911, the task of philosophy was to reclaim the spirit of classical European thought, and re-cast it in the light of the new sciences of psychology and biology. Yet in Einstein's famous 1922 objection to Bergson's “durational” conception of time, the physicist appealed not only to his own science, but also to psychology, as the only possible sources of temporal experience. For Einstein, Bergson's conception of

experimentation as an investigative approach in the humanities see e.g. Fitzgerald and Callard 2015. The relation between the present organizational and presentational mode and the topic at hand emerges throughout the discussion. Enquiries regarding editorial access to CSlide are welcome at quick.tr@gmail.com.

${ }^{2}$ For prior historical consideration of Bergson see e.g. Grogin 1988; Antliff 1993; Gilles 1996. 
time, on which the latter had founded his thought, simply did not exist: there was only a psychological time that differed from the physicist's (Anon. 1922, 107; translation from Canales 2015, 5). Furthermore, Einstein found support for his assertion from the only authority on psychology present at the debate. As Canales notes (though she doesn't develop the point), Henri Piéron suggested there that both Einstein and Bergson's perspectives could in fact be experimentally demonstrated, in the laboratory (Canales 2015, 244-246; Anon. 1922, 112-113). On the one hand, Einstein's physical time was revealed in the operation of the experimental psychologists' instruments. On the other, Bergson's duration could, just as Einstein had suggested, be identified with experimentally demonstrable temporal experience - and was in fact a psychological phenomenon of a different order to (and without influence on) physical time.

In response to these challenges, Bergson began to re-consider the relation between his philosophy and the sciences. Though he sought to remain open to the conclusions of experimental endeavor, his approach to science as a whole became more circumspect. Creative Evolution had confidently asserted the harmony of its appeal to an intuitively-derived "duration" with emerging biological and psychological research. Duration and Simultaneity ${ }^{3}$ (1922) would in contrast cast philosophy and physical science as "unlike disciplines ... meant to implement each other" (Bergson [1922] 1999, xxvii; Canales 2015,14). Why was it that Bergson did not contest Piéron's interpretation at the debate, merely noting that laboratory observation was "imprecise" (Anon. 1922, 113)? What had happened to cause him to lose confidence in the sciences that had seemed so philosophically promising eleven years previously?

This paper considers the significance of physiological and psychological endeavor conducted during the first decades of the twentieth century for evaluations of the scientific plausibility of what became one of the most emblematic conceptual tools of Bergson's philosophy - that of "the cinematograph." In so doing, it suggests that, by 1922, the scientific landscape in which Bergson had placed so much hope had shifted under his feet. The incorporation of cinematographic equipment into physiological and psychological investigation, it suggests, played a critical role in the re-organization of relations between physiology, psychology, and philosophy at this time. Indeed, Bergson's generous comments at Oxford regarding biology and psychology may well even have contributed to this trend. In 1913, Oxford appointed a new Waynflete Professor of Physiology, Charles Scott Sherrington. In 1906, a year before the emergence of Creative Evolution, Sherrington had published a monograph, The Integrative Action of the Nervous System, ${ }^{4}$ that would become an exemplary study to twentieth-century physiologists. ${ }^{5}$ Notably, the final chapter of this work centered on a set of experiments that adapted cinematographic devices to very different purposes than those that Bergson suggested typified scientific endeavor. Having cemented his

\footnotetext{
${ }^{3}$ https://cslide.medsci.ox.ac.uk/items/view/8470 (last accessed September 11, 2017).

${ }^{4}$ https://cslide.medsci.ox.ac.uk/items/view/3254 (last accessed September 11, 2017).

${ }^{5}$ On Sherrington, see Smith 2003; idem 2001b; idem 2000; idem 1992, 179-190; Swazey 1969, esp. 1-29.
} 
reputation with this publication, Sherrington would go on both to prevent followers of Bergson from gaining a scientific foothold in Britain, and to contribute to undermining the claims of internationally renowned thinkers who found common ground with him. Though he never cited and appears never to have met Bergson, Sherrington became one of the foremost representatives of an intellectual tradition that, at least until very recently, seemed impervious to his thought. Cinematographic devices, this paper contends, played a critical role in the creation of this circumstance.

The relation between philosophic and scientific investigation during the first decades of the twentieth century was actively shaped by considerations of and experimentation with cinematographic devices. Recent work on the relation between cinematography, physiology, and psychology has highlighted ways in which appeal to the recording and projection of imagery accompanied a re-conceptualization of scientific objects: where pictorial and photographic visualization had fixed and stabilized organisms, cinematographic recording demonstrated their motility and mutability (Cartwright 1995, esp. 20-29; Winter 2004; Landecker 2006; idem 2011; Schmidgen 2012). In contrast with these studies, this paper draws on film studies literature to consider cinematographic equipment itself as it was utilized in experimental endeavor. Two cinematographs might be said to have been simultaneously present in early-twentiethcentury physiological, psychological, and philosophical thought: that of the technical cinematograph utilized in laboratories, and the conceptual cinematograph which came to prominence as a philosophic trope in Bergson's texts. Emphasizing the mediating function of cinematographic devices rather than the cinematographic recording or projection of images brings to the fore their dual function in relation to scientific and philosophic practice at this time. ${ }^{6}$

On the one hand, this paper addresses the historical cinematograph as it existed amongst a range of illusion-generating devices utilized as research tools in laboratories, didactic tools at exhibitions, and as fairground-like "attractions" during the nineteenth and early twentieth centuries. As historians of cinematography have noted, a machine typifying "the" cinematograph has never existed as such. Rather, cinematographic image-recording devices emerged in conjunction with a much broader range of equipment designed to produce temporal and spatial illusions (Mannoni [1994] 2000; Gunning [1986] 2006). On the other hand, however, primarily through Bergson's influence, "the cinematograph" came to be understood within philosophy (and later film studies) as a device that stood in for a more general critical stance vis-a-vis the nature of perceptual experience. For twentieth-century philosophers, the cinematograph came to stand for a mode of intellectual practice which sought to differentiate temporal existence into distinct, static elements which could be re-assembled to constitute new ('natural') wholes. As Elie During and others have shown, the cinematograph as Bergson characterized it was in many respects an idealized object rather than an analogy with a

${ }^{6}$ I employ "device" rather than "tool" or "thing" here to denote the literary as well as practical uses to which cinematographic objects were put. On "epistemic things," see Rheinberger 1997. 
tool that existed in practice. Bergson's cinematograph was an epistemic device that incorporated such as-yet unusual features as full automation (and with it absolute constancy of temporal progression), and ignored the phenomena of "persistence of vision" that, as this article will further highlight, was fundamental to the development of the (quite different) tools after which it was named (During 2015; Tortajada 2011; Douglass 1999). This paper shows that, despite their differences, the fates of the cinematograph of the "cinema of attractions" and the cinematographic device of Bergson were intimately related.

Though it emphasizes the epistemic significance of illusion-generating devices for physiologists, then, this paper also addresses scholarship concerned with Bergson's engagement with science via his cinematographic conception of perception. The plausibility of Bergson's conceptualization of the cinematograph for experimentoriented scientists, it contends, depended on a historically specific set of intellectual relations in which physiology, psychology, and philosophy addressed a shared range of concepts and natural objects. The overlap between these endeavors allowed Bergson to famously portray the operation of the cinematograph as characteristic of the study of physical nature, and position the experience of "duration" as inaccessible to such study. This paper shows however that the very set of devices that Bergson named his conceptual formulation after in fact also contributed to the emergence of "durational" phenomena such as persistence of vision as physiological and psychological objects. In so doing, these devices, alongside those physiologists and psychologists that engaged with and constructed them, participated in a more general re-formulation of their respective endeavors as disciplinarily distinct. Where the physiological psychology of the turn of the twentieth century was marked by a negotiation between philosophical, psychological, and physiological claims around a single object (the embodied mind), physiologists and psychologists of the 1920s had begun to conceive of each other as working in disciplinarily distinct fields. Each of these enjoyed a particular relation to philosophy. This conceptual change was both dependent on appeals to the epistemic primacy of technical entities such as constituted the cinema of attractions, and problematic for Bergson's claim that his philosophy accorded with the conclusions of positive science. Attending to the device of the cinematograph thus not only presents a means of better understanding historical changes to scientific epistemology such as those outlined by Lorraine Daston and Peter Galison (2007), but also brings to the fore a significant episode in the history of relations between metaphysics and knowledge concerning nature more generally. Though Daston and Galison present a more satisfying account of the epistemological concerns of turn-of-the-twentieth-century scientists than did Bergson, they similarly characterize the technical epistemology of the time as "mechanical." This paper shows that such terminology obscures both conceptual changes within early twentieth-century physiology and psychology, and the historical status of tools as participants in these changes.

The study splits into two parts. Each addresses cinematographic devices in one of the aforementioned ways that they were present in early twentieth century intellectual 
practice. The first part thus examines Bergson's cinematographic characterization of mechanism, along with the "vital" evolution to which he opposed it. It considers the relevance of this opposition to Sherrington's physiological science, thereby examining the interaction between mechanical, vital, and physical modes of explanation in physiological psychology at this time (Young [1970] 1990; Smith 1973; Daston 1978; Jacyna 1981). Two conclusions emerge from this part of the study: first, that Sherrington should be identified as a key figure in the importation to Britain of physical approaches to physiology that had developed in Germany during the 1860s; and second, that this importation contributed to the breakdown of Bergson's characterization of physiology as split between vitalist and mechanist modes of scientific explanation. Whilst Bergson's interpretation of scientific intellect as cinematographic was particularly appropriate in relation to mechanistic approaches to bodily investigation, the increasing prominence of physical physiology undermined Bergson's contrast between (cinematographic) mechanical and (non-cinematographic) vital science. The notions of vital action in which followers of Bergson - including colleagues of Sherrington's - invested were thus increasingly coming to be assimilated into the physically-oriented science of the nervous system that came to prominence in the half century or so leading up to the First World War. Bergson's physiological alternative to the mechanistic conception of life - which he characterized in terms of his 'élan vital' - had by 1922 come to be understood as physiologically obsolete.

The second part of the paper highlights however that it was not the implausibility for physiological researchers of Bergson's claims that had the most significant implications for the status of his contentions, but rather a set of epistemological and institutional changes that occurred within physiology and psychology. It emphasizes that the establishment of technical epistemic commitments within these sciences during the late nineteenth century contributed to the emergence of disciplinary boundaries between these fields. Drawing on recent historical work addressing the roles of media tools in physiological and psychological investigation (de Chadarevian 1993; Brain and Wise 1994; Otis 2001; Schmidgen [2009] 2014; Cat 2013; Brain 2015), it shows how the engagement by Sherrington and others with devices that emerged from within the cinema of attractions contributed to the breakdown of the physiological psychological presumption that philosophic and physiologic investigation shared common categories of analysis. Bergson's contention that Einstein's physics could not escape referring ultimately to his philosophic concept of "duration" relied on an epistemic claim that the nature of the body (and by implication nature more generally) could be apprehended by vital mental effort. As it came to be appreciated within experimental physiological and psychological science, the cinematograph, rather than epitomizing the tendencies of mechanical philosophy, in fact embodied the technical refutation of this claim. The mediating device of the cinematograph thus operated not as a clue to the nature of scientific perception, but rather as a means by which epistemic attitudes were actively shaped and established. 
In this latter spirit, this paper also appeals to a mediating device - a website ${ }^{7}-$ in an attempt to embody as well as articulate its claims. By following the hyperlinks inserted at intervals through the paper, the reader is invited to engage with the sources on which its relies more directly than is possible in a narrative format. It is hoped that such engagement will facilitate more acute critical appreciation of the discussion than might be afforded by perusal of a printed text alone.

\section{Part I.: Bergson's Cinematograph and the Emergence of Physical Physiology in Britain}

\section{Sherrington and Mechanical Observation ${ }^{8}$}

As one of the first scientists to be trained in the newly-founded physiology laboratories of 1880s Britain, Charles Scott Sherrington was early on immersed in a culture in which the recording, measurement, and delineation of bodies held precedence over discussion of what might contribute to their creation. The laboratory founded by Michael Foster at Cambridge, where Sherrington completed his undergraduate studies, took its epistemic cue from the simultaneously-founded Cavendish physics laboratory. Figures such as Foster, John Newport Langley, and Sherrington's mentor Walter Holbrook Gaskell strove there to develop means by which the rhythms of living organs and their relation to one another could be made visible and mappable, and thereby subject to precise calculation (Geison 1978, esp. 112-115). At the Cambridge laboratory mechanical recording and anatomical mapping went hand in hand, and ultimately held out the prospect of the development of explanations of the relation between organic activities and organs of the body that were consistent with the laws uncovered at its physicsoriented sister institution.

Sherrington's early research fitted closely with the aims and goals of his Cambridge mentors. In particular, his laboratory training placed him in a position to take advantage of the emergence of a relatively new technique of nerve investigation: that of the instigation of "secondary degeneration" in experimental animals. Though experimental intervention in nerves had become increasingly routine for French and German physiologists by the 1860s, and the phenomenon in which nerves disintegrated following the introduction of a lesion to them had been described by Augustus Volney Waller as early as 1850, it was only during the 1870 s and 1880 s - when Sherrington was a student at Cambridge - that "degeneration" studies began to be taken up by British physiologists in any systematic manner (Lesch 1984, 175-178, 191196; Clarke and Jacyna 1987, 197-202, 249-259; Lawrence 2009, 456-457, 464-466). Starting in 1884 , Sherrington gradually built up a reputation as one of degeneration's

\footnotetext{
${ }^{7}$ https://cslide.medsci.ox.ac.uk/ (last accessed September 11, 2017). See note 1.

${ }^{8}$ https://cslide.medsci.ox.ac.uk/items/view/8783 (last accessed September 11, 2017).
} 


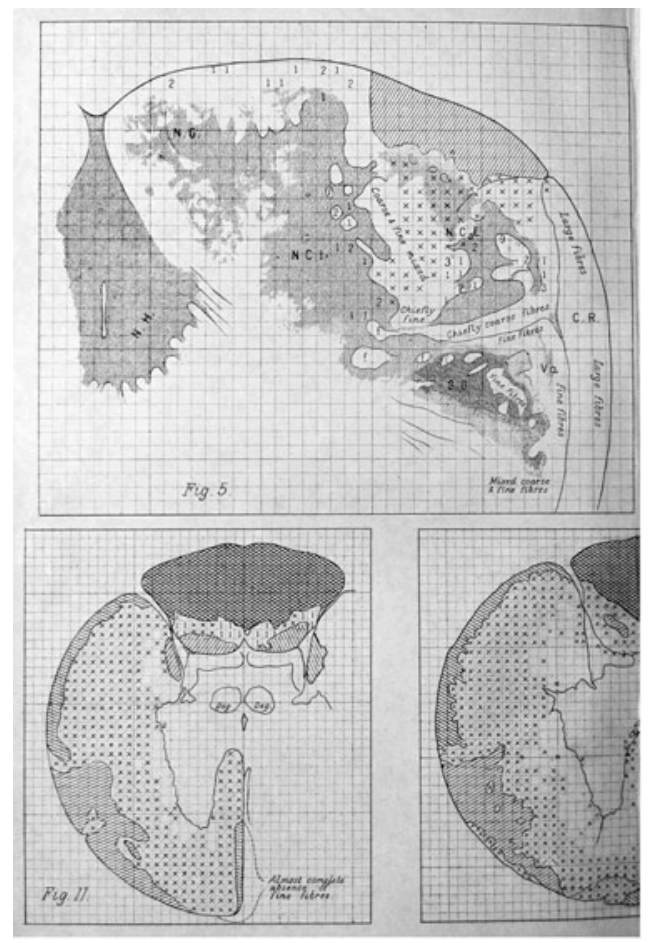

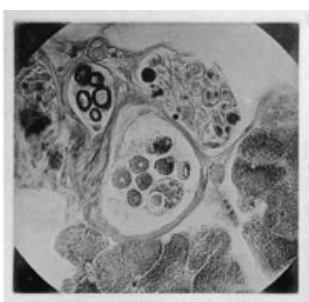
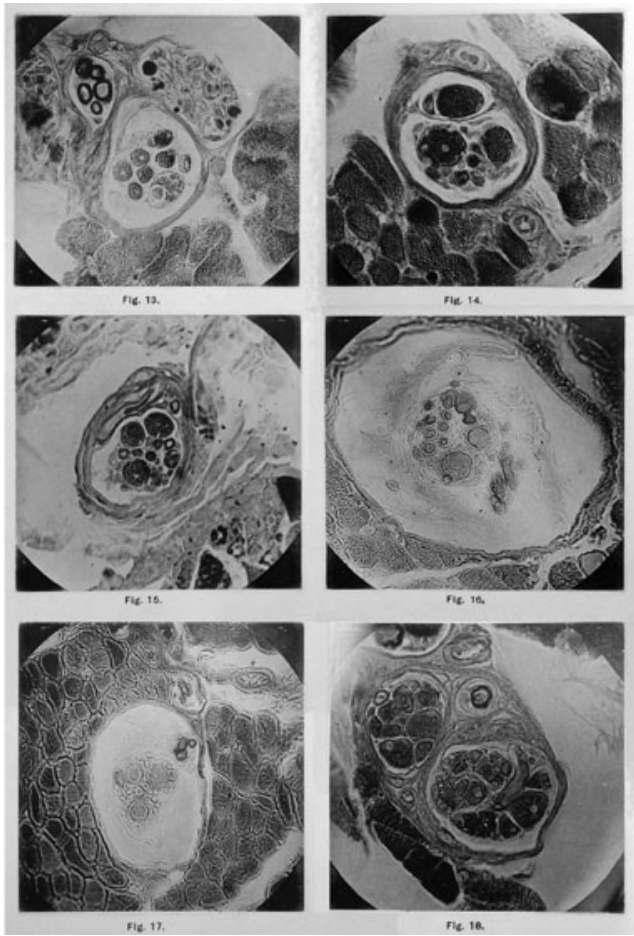

Figs. 1 (left) and 2 (right). Left: part of plate XIV ${ }^{9}$ from Sherrington 1893. Right: plate VII ${ }^{10}$ from Sherrington 1894.

most acute and productive proponents. His approach, which came to be known as "successive degeneration," was simple: first, identify the areas of a body at which electrical stimulation produced a particular reaction; and second, systematically cut the nerves leading away from these areas, applying further stimulation as each nerve is cut (Swazey 1969, 57-60 and 63-66). By monitoring changes in the reactions of the animals subjected to this technique, it would (experimental physiologists believed) be possible to identify the specific nerves responsible for the instigation of specific bodily activities. Bodily functions, it seemed, could be linked to the structure of the nervous system with hitherto unattainable accuracy.

For the first two decades of his career, Sherrington presented his degeneration studies as cautious contributions to the gradual accumulation of evidence regarding the mechanical nature of nervous life. He focused almost exclusively on the simpler forms of nervous existence (especially those associated with antagonistic muscular

${ }^{9}$ https://cslide.medsci.ox.ac.uk/items/view/7708 (last accessed September 11, 2017).

${ }^{10}$ https://cslide.medsci.ox.ac.uk/items/view/7521 (last accessed September 11, 2017). 
actions such as the "knee jerk") (Swazey 1969, 52-55). Furthermore, the mode in which Sherrington presented his work owed as much to the formulae, tables, and calculations of the Cavendish physicists as it did to the anatomic accuracy of his physiological mentors. Rather than present lavish hand-drawn illustrations of his nerve investigations, as had Gaskell, Sherrington supplied tables of response measurements, graphs of reaction-intensities, and introduced grids with which he might reduce the complexity of nervous anatomy (fig. 1). His study addressing the pioneering histological work of Angelo Ruffini similarly replaced the latter's all-encompassing delineations with a series of microphotographs (fig. 2) (Sherrington 1893; Sherrington 1894). Sherrington's work was well received. As James Mussell highlights, his papers came to be held up as exemplars of effective scientific communication (Mussell 2009, paragraphs 17-22). The science of experimental physiology as it developed in Sherrington and his contemporaries' work can thereby be closely associated with a tendency towards the analysis and delineation of nature by technical means. These means, furthermore, were by-and-large applied within an already well-established epistemic mode: that of the "analytic" reduction of natural objects into comparatively simple components, and the "synthetic" reconstruction of these into new natural wholes (Pickstone 2000, esp. 117-121; see also Canales 2011, 345-351).

Bergson characterized the analytic and synthetic mode in which much midto-late nineteenth-century physiology was conducted as "mechanical." Though he initially articulated the critical stance he would apply to physical and physiological endeavor in relation to the German tradition of psychological research, and especially that of Wilhelm Wundt and Gustav Fechner (see Carroy and Schmidgen 2002, 13; Heidelberger [1993] 2004; Araujo 2016), in Creative Evolution he identified British physiological psychology as its principle object of philosophic concern. In this work Bergson identified such writers as Herbert Spencer and Alexander Bain with what he characterized as a particularly problematic intellectual trend. Spencer and his contemporaries had articulated what they understood as a simultaneously mechanical and philosophic psychology, in which nerves were conceived as the material corollaries of mental states (Young [1970] 1990, esp. 172-180; see also Daston 1978; Smith 2013, 45-49). Though he concurred with physiological psychologists' combination of biological research and metaphysical speculation, Bergson opposed what he called Spencer's "false evolutionism," which he identified with the latter's purported belief that it was possible to reduce the entirety of nature to "fragments." Furthermore, Bergson found the more general associationist claims of which Spencer's philosophy partook unconvincing (Bergson [1907] 1911, xiii). Starting with Matter and Memory ${ }^{11}$ (1896), Bergson consistently opposed what he characterized as the mechanism-oriented "mathematical deduction" of thinkers such as Wundt to his own conception of philosophically-lived experience (McGrath 2015, 11-16). This latter, he suggested in

\footnotetext{
${ }^{11}$ https://cslide.medsci.ox.ac.uk/Items/view/8495 (last accessed September 11, 2017).
} 
Creative Evolution, was constituted not primarily by a set of bodily or material conditions, but by the interrelation of sets of thought-images which the philosopher (he supposed) brings into contact.

From this position, Bergson developed a critique of the scientific realism that he claimed mechanism-reliant analysis of nature relied upon. Those who adopted associationist assumptions in their investigations of nature were, he suggested, unable to reconcile two radically different claims to which they adhered: firstly, that nature in fact consisted in material changes within space that could be reduced to a series of capturable moments; secondly, that these moments could be arranged in consciousness as a set of natural objects - that each captured moment could be retained and re-arranged into a coherent, calculable whole (Bergson [1889] 1910, e.g. pp. 75-79; idem [1896] 1988, e.g. 69-71). In Creative Evolution, Bergson characterized these assumptions as "cinematographic." Against this view, he posited a re-appraisal of the role of immediate experience in the establishment of knowledge. By immersing oneself in the world, he claimed, it would be possible to evolve a fuller conception of existence: one in which space and matter would be re-assessed in terms of a more fundamental temporal experience, referred to as "duration."

\section{Bergson's Physiological Psychology ${ }^{12}$}

By 1907, Bergson had come to rely on a particular strand of biological thinking that he believed accorded more closely with his philosophy than did the claims of mechanists. Matter and Memory had conveyed a conception of existence in which memorial experience transcended both subjective ("idealist") and objective ("realist") enquiry (Bergson [1896] 1988, 69-71). By the time Creative Evolution came to be published, however, Bergson was willing to go further: biological science was to be returned within the purview of philosophy, as it had been in classical European thought. This was to be achieved, he argued, through the constitution of a theory of knowledge that, because based in immediate experience, would also be a theory of life. "Together," he contended, these theories would "solve by a method more sure, brought nearer to experience, the great problems that philosophy poses." By thinking together a set of contentions regarding the originary nature of life with his own conclusions regarding the nature of memory and experience, it would be possible to arrive at a situation in which biological and indeed all science would appear merely as "psychics inverted." Ultimately, living matter evinced an "intuitive" psychological process which was "in its essence ... an effort to accumulate energy and then to let it flow into flexible channels, changeable in shape, at the end of which it will accomplish infinitely varied kinds of work.",13

\footnotetext{
${ }^{12}$ https://cslide.medsci.ox.ac.uk/items/view/8787 (last accessed September 11, 2017).

${ }^{13}$ Bergson [1907] 1911, quoted on pages xiii, 202, and 253-254. See also idem [1896] 1988, e.g. 28-31 and 41-46 (on intuition in Bergson, see Massey 2014).
} 
Philosophical practice similarly consisted in a process of accumulation and dissimilation, of conscious awareness. Philosophically-lived experience should alternate between an intellectual state in which the "whole personality concentrate[s] itself," and a dreamlike, "scattered" state in which the originary nature of matter becomes perceptible. The vital mind thus "uses" space "like a net with meshes that can be made and unmade at will, which thrown over matter, divides it as the needs of our action demand" (Bergson [1907] 1911,201-202). The life sciences, properly conducted, constituted an intuitionguided investigation of the processes of extension and retraction as they manifested themselves in the living substance.

Recent historiography on relations between psychology and life science in Europe at the turn of the twentieth century suggests that the hope that Bergson held out for the latter was by no means misplaced. For example, Judy Schloegel and Henning Schmidgen point to the prominence during the final decades of the nineteenth century of a physiological tradition in which psychological existence was associated with that of the most simple known forms of organic matter; in the work of Ernst Haeckel, Max Verworn, and Alfred Binet, amongst others, psychological properties such as sensation, volition, and intention were discovered in apparently primordial forms of life, most notably the cell (Schloegel and Schmidgen 2002, esp. 622-633). Though these investigators differed regarding the extent to which they regarded such properties as inhering in protoplasmic or nucleic parts of cells, all agreed that each could be considered an independent psychic unit. Human psychology was the manifestation of the simultaneous action of the countless autonomouslyacting individuals that composed their bodies: properly understood, mind was indeed able to dissimilate into its originary nature. Histological studies of nerve cells and their relations thereby came to carry particular weight within physiological psychology.

One of the most pressing questions facing those who adhered to cell-centered conceptions of psychology was how independently-acting individuals could combine to form more complex psychological wholes. Different tendencies existed within the conceptual framework of cellular individuality. One contention that gained considerable traction during the final years of the nineteenth century was the socalled "amoeboid" theory. Just as individual cells could be identified as manifesting vital capacities such as autonomous extension and contraction, each nerve-cell or "neuron" was in the conception of such histologists as Mathias-Marie Duval an independently-acting contributor to the neurological whole. Ramón y Cajal suggested in a study of 1890 that nerve fibers could be seen to grow outwards from their cellular origins. He and like-minded theorists believed at this time that such observations constituted evidence that nerve cells behaved just like amoeba, in that they expanded, contracted, and moved their extremities from place to place (Black 1981, on 35-36 and 38-39). The possibility of psychological variation was thereby assured: by altering the proximity of each cell to one another, amoeboid movement altered the extent to which electrical nerve-impulses could be communicated. The 
psychologically-individual cells of the nervous system combined to create a greater whole.

Contrasting with this conception of cellular activity was an alternative, "network"centered vision of neurological connection (Otis 2001, 55-69). Though the notion that the body was permeated by a fibrous network of nerves through which organs communicated had been prominent in physiology prior to the nineteenth century, this had been sidelined as the cell theory had been established (Clarke and Jacyna 1987,311315. 350-367). In 1869 however, Thomas Henry Huxley prominently declared a new network-making substance, "protoplasm," the "physical basis of life." First propounded by Max Schultze in 1860, it had been Haeckel who presented the most influential discussion of its relevance to psychology. As Brain notes, Haeckel's contention that that protoplasm "had the ability to receive and maintain the waveform vibrations of the external world" and thereby pass on organic characteristics from one generation to the next achieved great prominence during the late nineteenth and early twentieth centuries. Haeckel further argued that a protoplasmic capacity for the reception and storage of wave-forms endowed cells with a psychological capacity (Brain 2009, on 9495 and 101-104). Well into the twentieth century, histologists such as Camillo Golgi, Hans Held, Stephan Apáthy, and Albrecht Bethe presented evidence that nerves could link together via continuously connecting organic structures (Breidbach 1996, 200201). A significant strand of late nineteenth-century physiological psychology thereby identified the variability of nervous excitation not with the properties of individual cells as such, but with the vital and extensible properties of the protoplasm common to them all.

Adherents of cellularly-distinct conceptions of neuronal connection portrayed them as confirming associationist contentions regarding the nature of psychology (Black 1981,44-45). For example, the American physician Francis Xavier Dercum argued that the "amoeboid" expansion and retraction of individual cells underlay variously hysteria, hypnotic, and dream states, sleep, and trains of thought themselves. These latter, Dercum contended, appeared "to follow purely mechanical lines" of association and disassociation between the sense impressions that they carried (Dercum 1896, esp. 520-523, quoted on 522; emphasis in the original). In 1898, Boris Sidis and Ira van Gieson elaborated this thesis to account for states of sanity and insanity: in Gieson's words, "unsoundness of mind" was caused by the "dissociation" of the "higher and last evolved parts of the brain, in the presence of pathogenic stimuli" (van Gieson 1899, 87; Sidis 1919, 208215). For amoeboid theorists, the apparent mechanical capacity of nerve cells to alter their proximity to one another presented physical confirmation of the existence of psychological associations.

In a similar way, adherents of the protoplasmic conception of neuronal connection identified mental activity with the presumed properties of this vital substance. Especially prominent amongst these was the renowned German physiologist Ewald Hering. Calling for physiologists to "cease considering physiology merely as a sort of applied physics and chemistry," Hering argued that the causes of nervous action were to 
be found in two independent and contradictory tendencies of protoplasmic matter (Hering 1900, 169.). On the one hand, a tendency towards "assimilation" could be perceived within living substance. This was balanced by an equal and opposite tendency, that towards "dissimilation." Where assimilation predominated, organic matter increased in activity. Where dissimilation predominated, activity decreased. The variable energetic states of protoplasm expressed itself in the nervous system as the throwing-out of countless connections between cellular bodies: "a nerve-trunk is ... a bundle of living arms which the elementary organisms of the nervous system send forth for the purpose of entering into functional connection with one another, or of permitting the phenomena of the outside world to act upon them, or of exercising control over other organs" (Hering 1900, 177-178). Sensation was not so much the consequence of impressions on sensory organs that were then conveyed to the mind via the nerves, as the establishment of sympathetic rhythms between the various realms of existence. Thus in the case of visual sensations, Hering argued that protoplasm vibrated according to the frequency of light-waves connecting with the retina (Hering 1900, 183, 186). Brain recounts how at the Paris Société de Biologie, Binet and others developed similar explanatory schema to account variously for hypnotic and hysteric states, sleep, aesthetic experience, and even paranormal phenomena (Brain 2013, 125-127). Protoplasm spread both inwards and outwards from the vital mind, bringing mental life into vibratory harmony with all that it touched.

Given Bergson's dissatisfaction with associationism it is not surprising that he found particular inspiration in this protoplasmic conception of psychological activity. In its insistence on the active, temporally extensive nature of both bodily and psychological existence, Creative Evolution appealed to a particular research tradition within physiological science. For Bergson, such studies as those detailed above indicated that "life is a movement, materiality is the inverse movement, and each of these two movements is simple, the matter which forms a world being an undivided flux" (Bergson [1907] 1911, 249). Just as the philosopher brought thought-images into contact with one another, protoplasm formed psychic connections amongst material nature. Here then was confirmation of the philosophical import of physiological investigation: to the extent that physiology confirmed the evidence of "intuitive" experience, it presented a means by which the philosopher might demonstrate the creative presence of thought within the body.

Bergson not only asserted the scientific relevance of his own views regarding life and mind, however, but also argued for the superiority of his own approach over that with which he contrasted it. To do so, he employed a vivid metaphor. As already noted, Bergson suggested that both mechanistic science and associationism had adopted and expanded out of all proportion a tendency within classical philosophy (exemplified by the paradoxes of Zeno of Elea) in which phenomena were considered in terms of series of isolated moments (Bergson [1907] 1911, 308-313; see also Bergson [1896] 1988, 188-193). The fallacy of this tendency, Bergson suggested, was revealed in the 
mechanics of an idealized cinematograph. During the nineteenth century conscious experience had been for Bergson an automatic, passive recording device that captured a series of images as they passed before it. Reconstituting or replaying this series in memory had created an illusion of change. But such re-constitution was only that: an illusion. Once, through an examination of the cinematographic mechanism, one became aware of the illusory nature of serial sensation, it would be possible to attain a truly philosophic sense of time and nature (Bergson [1907] 1911, 304308). Intuitive philosophy would reveal that life and mind were not an agglomeration of innumerable isolatable elements and moments, but a single, flowing continuity of image-relations that could not be differentiated without loss of awareness of the whole.

Nevertheless, as will be shown, the biological propositions to which Bergson appealed to legitimate his philosophic approach were highly contentious amongst physiologists. For example, Sherrington's above-mentioned microscopic studies emerged out of an extended consideration of the nature of cellular life. These emphasized the functional significance of strictly mechanical cellular bodies. And it was the mechanical emphasis within British physiology that constituted the interpretive context for physiological and psychological studies that utilized cinematographic equipment in laboratories. The rest of this two-part paper then takes Bergson's suggestion that examination of cinematographic mechanisms might provide a clue to the study of perception as a cue for historical investigation. Despite the broad validity of his characterization of scientific realism at the end of the nineteenth century as centered on technical representation (Daston and Galison 2007, esp. 11-16, 138-161), Bergson was not fully aware of the significance that the equipment that constituted the cinema of attractions had in fact attained in the physiological laboratories of Europe and the United States. The use of cinematograph-like devices in laboratory investigation did more than facilitate the reduction of natural objects to singular analytic components (as Bergson suggested it would). Their adaptation and use also helped to constitute quite different conceptions of both physiological and psychological nature than had been conceived of hitherto. Indeed, experimentation with cinematograph-like devices facilitated the assimilation within experimental science of many of the contentions that Bergson introduced via his vital philosophy. Moreover, the negotiation of how such devices could be used effectively within these fields contributed to a more general differentiation between physiological and psychological disciplines. As already noted, Bergson's appeal to intuitive experience as a means of interrogating vital nature was grounded in a mode of scientific organization in which philosophical, physiological, and psychological claims spoke directly to one another. This organizational mode did not survive the assimilation into it of the very kind of device that he brought to bear in his characterization (and rejection) of established scientific epistemology.

Before detailing this assimilation itself, however, it is first necessary to note the differing contexts in which illusion-generating mechanisms were in fact appealed to in physiological science: it was by no means coincidental that physiologists such 
as Sherrington, trained as they were in the precision measurement and mechanical delineation of bodies, played a critical role in the above-described process. Bergson's characterization of scientific methodology appears to have been apt as far as both Marey's studies and Wundt's program of "psycho-physics" was concerned (Carroy and Schmidgen 2002, 13). However, the almost exclusive emphasis within British physiological psychology on the association of spatially (rather than temporally) differentiated perceptual elements helped constitute very different conditions for the utilization of equipment relating to the cinema of attractions within laboratories than those present in France and Germany.

\section{Physical Psychology and Inhibition in Britain ${ }^{14}$}

In Integrative Action, Sherrington broke with the physiological traditions in which he had been trained to articulate a holistic conception of nervous action that centered on a physical (rather than simply mechanical) interpretation of the interaction between nervous elements. In so doing, he aligned himself with the German tradition of "organic physics" (Lenoir 1987). Cells featured particularly prominently in his analysis. In the opening words of the book he declared that "nowhere does the cell-theory reveal its presence more frequently in the very framework of the argument than at the present time in the study of nervous reactions." Furthermore, he suggested, "the progress of natural knowledge" had enabled biology to pass "beyond the confines of the study of merely visible form, and ... [turn] more and more to the subtler and deeper sciences that are branches of energetics" (Sherrington [1906] 1947,1). Such emphasis on the physical nature of nervous activity was not without its problems however. For example, whilst discussions of the physically-derived activities of individual nerves might be brought to bear in analyses of nervous action, the physical means by which cells interacted remained far from clear. Indeed, as already discussed, many of the most plausible explanations of nerve cell interaction centered on properties considered unique to life rather than concepts drawn from physics. In developing his conception of nervous action, then, Sherrington was forced to engage directly with traditions of research that lay outside his training.

Despite Sherrington's physicalist sympathies, he (like most late nineteenth-century physiologists) remained firmly within a natural philosophic discourse in which philosophers, psychologists, and physiologists shared both conceptual terms and objects of explanation. Roger Smith has shown for example how the concept of "inhibition" served as a place-holder for debates regarding mental hierarchies at this time. Able to denote both the suppression of nervous response and the control of bodily impulse, inhibition constituted a site at which physiological and psychological claims came together to address a common object. At stake in discussions of it was not

\footnotetext{
${ }^{14}$ https://cslide.medsci.ox.ac.uk/items/view/8789 (last accessed September 11, 2017).
} 
only the possibility that nerve activity might depend on the autonomous actions of psychologically individual cells, but the relation between mind, the brain, and the nervous system more generally (Smith 1993, 16-19; see also Smith 1973). For most physiologists, inhibition denoted a negotiation of relations between the latter two of these categories. Was the suppression of certain actions and the manifestation of others due to changes in individual nerves or to some other cause such as cerebral influence? How, if not by the autonomous creation and destruction of links between themselves, could nerves manifest variable levels of response to stimuli?

Sherrington was not the only physiologist to appeal to physical modes of explanation at the turn of the twentieth century. Physically-inclined physiologists such as Emil du Bois-Reymond's students Ludimar Hermann and Julius Bernstein sought to articulate conceptions of inhibition that a) did not rely on an appeal to vital forces inherent to cells, and b) could nevertheless account for the psychological processes in which particular nerve functions predominated over others. For example, the emergence of osmotic concepts within physical chemistry at this time prompted a re-evaluation by physiologists of the widely-held assumption that the wave-like electrical phenomena produced by nerves was a product of the release of a kind of chemical energy specific to them (Lenoir 1986, 19-26; Finkelstein 2013, 182-187). Physical chemists working in the 1880s and 1890s had begun to portray electrical potential as a product of the internal dynamics of battery cells. By introducing a semi-permeable membrane between differently-concentrated solutions of liquids, investigators argued, it was possible to model electrochemical phenomena in terms of the production and release of "osmotic pressure": galvanic current was produced by the migration of ions between differently-concentrated regions of a battery cell (Barkan 1999, 46-57). At the end of the nineteenth century, Bernstein influentially drew on such contentions to develop a mathematical model of electricity transmission that did not require any expenditure of cell-specific energy: his model rather showed that changes in rates of transmission were due to ionic exchange (Lenoir 1986, 39-47; Seyfarth 2006; cf. De Palma and Pareti 2011). For a small number of physiologists working at the start of the nineteenth century then, bio-electricity could no longer be considered the product of a vital force: rather, it was the result of an in-principle calculable alteration in ionic densities between liquids.

With his 1897 appointment as Holt Professor of Physiology at the University of Liverpool, Sherrington had been afforded a front-row seat from which to follow these developments. In 1891, John Smyth Macdonald had been appointed a Holt Fellow at Liverpool under Francis Gotch. By 1899, he had attained the rank of Senior Lecturer, and had moved away from Gotch's emphasis on relating galvanometric changes to changes in body temperature (O'Connor 1991, 335-336). Instead, Macdonald began to identify electrical variability with interactions between nerve cells and their environments. Macdonald suggested that nervous current was produced not within a single, undifferentiated cell, but by interaction between a series of ion-carrying "relays placed at every point of the nerve to ensure the continuous propagation of the excited 
state" (Macdonald 1905, 323-324). Significantly, these relays presented an explanation for the both the variability and the uni-directionality of nerve conductivity (Macdonald 1905, 340). Like Cambridge contemporaries such as William Bate Hardy, Macdonald also doubted the existence of an autonomously-acting protoplasmic network extending outwards from nerve cells. He proposed in its place an explanation of the variability of nerve cell conductivity which appealed to the changing proportions of ion-carrying compounds in the fluids within and surrounding cells. Inhibition of individual nerve cells was thus due to "a reversible change during which electrolytes are set free into a state of simple solution, and are then recovered from this state back into their original condition" (Macdonald 1905, 330-333). The vibrations detected by protoplasm theorists were not the products of organic fibrils connecting inner life with its external conditions, but changes in the ionic concentrations of fluids behaving according to mathematical laws of osmosis.

It is not then surprising that in announcing his explicitly physical conception of neurological existence in 1906, Sherrington invested significantly in Macdonald's research. ${ }^{15}$ This was to a great extent due to the possibilities that he saw in it regarding a more general explanation of physiological inhibition. After a brief consideration (and rejection) of Gaskell and Hering's metabolic propositions, Sherrington devoted nearly three pages of Integrative Action to Macdonald's conclusions. Summarizing the latter's research as leading to the proposition that "inhibition is the condition in which the possibilities of free motion are most reduced," he suggested that Macdonald's views were "fertile in suggestion for future experiment" (Sherrington [1906] 1947, 197-200, quoted on 199-200). Such enthusiasm reflected a new emphasis within physiology on the study of nerve junctions themselves as sites at which conduction might be interrupted. In his Textbook of Physiology of 1900, Edward A. Schäfer had suggested that impulses were "momentarily arrested at these places of contact of nerve cells with one another," which he referred to as "synapses" (Schäfer 1900, 608). Sherrington, characterizing such interruptions as manifestations of a "neurone threshold," identified it unequivocally with a discontinuous synaptic transmission:

at each synapse a small quantity of energy ... acts as a releasing force to a fresh store of energy not along a homogeneous train of conducting material, ... but across a barrier which whether lower or higher is always to some extent a barrier. (Sherrington [1906] $1947,157)^{16}$

This insistence on the functional significance of barriers between cells marks a critical change of emphasis within physiological considerations of the causes of inhibition.

\footnotetext{
${ }^{15}$ See e.g. letter from C.S. Sherrington to H. Cushing dated January 22, 1902, and C.S. Sherrington to H. Cushing dated July 7, 1905 (Sherrington Collection, Box WCG 1-37. WCG 32.6 and WCG 32.13). This investment has been little-noticed: for example Smith's major study of the term does not address Macdonald's work (cf. Swazey 1969, 73-74).

${ }^{16}$ On Sherrington's earlier “reticulist” conception of synapses, see Black 1981, 55-56.
} 
Where explanations of variations in the rate of electrical transmission along nerves had centered on cells and the substances that composed them, Sherrington and his colleagues characterized such variability as dependent on changes in the thresholds at which transmission between cells could be effected. Neither cell bodies nor protoplasm were the most physiologically significant conditions for variation in the transmission of nervous impulses: rather, "synapses" were.

It would be a mistake however to suggest that Sherrington relied on strictly physicalist conclusions regarding nervous action to establish his contentions regarding inhibitory activity. Significantly, in the passage of Integrative Action immediately following that recommending Macdonald's research, Sherrington moved on to discuss a somewhat more complex aspect of the variation of nervous function. This section, which he disassociated from inhibition proper, concerned the effects of stimulation of more than one nerve at the same time.

\section{Sherrington's Physical Appropriation of Vital Psychology ${ }^{17}$}

It was well known amongst physiologists that if particular areas of an experimental animal's skin were stimulated, one response could be elicited for a certain time, following which an entirely different response might take over. Stimulations of the same points or areas of skin could elicit radically different actions depending on their longevity. Sherrington had sought to make this area of investigation his own. In a long series of notes presented to the Royal Society between 1893 and 1909, he set out to define the nature of the so-called "knee jerk" reaction, and with it what he would call "antagonistic muscle action." As a reaction that was dependent on the "reciprocal innervation" (i.e. simultaneous antagonistic action) of two muscles working in opposite directions, this latter topic presented a more complex problem than that concerning excitation of a single nervous pathway. The variability of antagonistic reactions, Sherrington found, was dependent on the initial posture of the animal, the extent to which stimulation had previously been applied, and the strength of the stimulus. Particularly notable were situations in which two reactions would alternate between one another (Swazey 1969, 84-90). In Integrative Action, such dynamic alterations constituted a significant steppingstone between the explanation of the inhibition of simple nervous reactions and that of reflex activities more generally.

As set forth in 1906, however, Sherrington's explanation of alternating "antagonistic" reactions appealed not primarily to his own studies, but to the research of the physiologist and psychologist William McDougall. As with Macdonald, Sherrington

\footnotetext{
${ }^{17}$ https://cslide.medsci.ox.ac.uk/items/view/9704 (last accessed September 11, 2017).
} 
knew McDougall personally. ${ }^{18}$ McDougall's explanation of reflex action was heavily indebted to Sherrington's studies of nervous action. Moreover, it identified the critical variable in the alteration of nervous response in functionally significant "gaps" between cells. Though previous studies had characterized inhibition as a phenomenon inherent to cellular physiology (for example in Hering's appeal to contradicting physiological forces within cells) such conclusions were not universally accepted. In opposition to such claims, McDougall ascribed the inhibition of all nervous processes to the predomination of others. Inhibition was, he suggested, "always the result of the setting in of some other mental process" (McDougall 1903, 155-160, 169). Thus, given two "antagonistic" nerve arcs entering a synaptic gap, the manifestation of one of these would prevent the other from gaining expression. Similarly, when an initiallypredominating reflex diminished in strength, the nerve arc that had not yet found expression would take over (McDougall 1903, 174-176). In an extended critique of theories of depth- and color perception prominent amongst German experimental psychologists, McDougall employed this schema to account for the wavering of attention between fields of vision when each eye was presented with different forms of stimulus (McDougall 1901a, 91, 242; on vision research in German physiological psychology, see especially Turner 1994; Hatfield 1990; Wade 2005). Here then was a conclusion that appeared complementary to Macdonald's studies. As in Macdonald, changes in nervous response were to be identified not with the activities of individual nerves, but with changing conditions at the sites of interaction between them. Synapses were sites at which peripheral nerves competed for access to what Sherrington would term a "final common path" that would register their stimulation more widely through the system.

Crucially, McDougall had arrived at his conclusions not primarily through experimental or anatomical study of nerves, but that of his own sensory impressions. After a period on the Cambridge University-led Torres' Strait expedition and a shortlived career in medicine, he had sought out the Göttingen psychologist Georg Elias Müller, "then the leading exponent of the exact laboratory methods in psychology" (McDougall 1961, 203-204). Despite reporting himself to have been "not in close intellectual sympathy" with Müller, this training had nevertheless brought him into contact with the few British psychologists who had begun to engage psychological experimentation at this time, including W. H. R. Rivers, and James Sully (McDougall 1961, 203-204). In an effort to import the German tradition of experimental study of mind to Britain, Sully had in 1897 acquired a set of laboratory equipment from Müller's rival Hugo Münsterberg that the latter had created for his own psychological laboratory in Freiburg (Valentine 1999, 212-213; on Münsterberg's equipment at Freiburg, see Schmidgen 2008, 2-3). Without experimental training of his own, Sully persuaded

\footnotetext{
${ }^{18}$ For example, one of McDougall's first actions on his 1904 appointment to the Wilde Readership of Mental Philosophy at Oxford was to invite Sherrington to lecture there. See letter from J.S. Burdon-Sanderson to C.S. Sherrington dated July 23 [1904] (Sir Charles Scott Sherrington Fonds, 428).
} 
McDougall to return to Britain to take up research at University College London. This in 1903 led to McDougall's appointment there in the newly-created post of Reader in Experimental Psychology. McDougall thereby spent the first years of the twentieth century living in a small house on the Surrey Downs, manipulating his visual experiences using a set of tools developed within the then-emerging German schools of experimental psychological research, and adapting his conclusions regarding these to the British context (McDougall 1961,205). In 1904, he was appointed Wilde Reader in Psychology at Oxford, thus becoming one of the foremost representatives of academic psychological science in Britain.

Furthermore, McDougall conveyed his findings in terms that went directly against the mechanistic and associationist tendencies of late nineteenth-century British physiological physiology. He began his career by rejecting the widely-held proposition amongst British physiological psychologists that mental faculties could be identified with one or another anatomical part of the brain or nervous system. Instead, he proposed, awareness was "immediately determined" by "neural processes" as a whole (McDougall 1898,15,365). Thus an increase in nervous excitability could be attributed to a "diminution of the resistance offered by that delicate and complex inter-cellular substance which, as it seems to me, we have to regard as the seat of the psycho-physical processes." According to McDougall this substance was not protoplasm, but a physicallyindependent vital fluid which he termed "neurin." Build-ups of neurin overcame the resistance of synaptic barriers, causing chains of like reactions through the whole system (McDougall 1901b, 590, 614, and 616). McDougall, then, considered his investigations as contributing to a different, but similarly vitalist tradition of research as that in which Bergson had invested: like Bergson, he characterized the defining attribute of life as an activity (flow) rather than a structure such as the cell; like Bergson, he accorded a nonrational concept ("instinct" rather than Bergson's "intuition") a fundamental role in the psyche (McDougall 1908); and like Bergson, he was fascinated by what he characterized as the as-yet unknown potentialities of vital existence. It is notable in this later regard that both served as presidents of the Society for Psychical Research (Valentine 2012, 70-71, 81). By the time Bergson spoke at Oxford, McDougall had begun to actively promote the philosophy of the former amongst his scientific peers (McDougall 1911, e.g. 84). In so doing, he became one of the few British scientists to explicitly take up Bergsonian themes in his work. For Sherrington then, McDougall represented his most immediate contact with a burgeoning tradition of research that, though it presented an alternative to the mechanical tradition that he was seeking to move away from, also threatened to undermine his own contentions regarding the physical nature of life.

Perhaps unsurprisingly, Sherrington's connection with McDougall appears to have caused consternation within Britain's community of mechanist physiologists. For example, when on his appointment to the Wilde chair McDougall invited Sherrington to lecture at Oxford, Sherrington's predecessor in the Waynflete chair, John Scott Burdon-Sanderson, wrote to the former expressing his surprise. In his note Sanderson related how he had "just become aware that you are to deliver a lecture here" at the 
behest of McDougall, that he could not "be sure whether it is to be on Physiology or Experimental Psychology," and requested that Sherrington attend luncheon with him after the lecture. He further added, with something seemingly approaching sarcasm, "if it would suit you ... to dine with us tout niveux [sic]."19 Sherrington had spent the previous two decades building up a reputation as one of the most productive physiologists in Britain, and identified Oxford as a place in which he might further his own physiological goals (he had unsuccessfully sought appointment there in 1895. Swazey 1969, 18-19). Burdon-Sanderson could thereby be sure that his expression of uncertainty regarding Sherrington's intellectual commitments would be well attended to.

Most likely mindful of the incompatibility of McDougall's views both with those of his mechanistically-oriented colleagues and his own physical commitments, Sherrington was careful in Integrative Action to avoid uncritical reliance on McDougall's conclusions. Despite his enthusiasm regarding McDougall's explanation of "reciprocal innervation," Sherrington's characterization of it limited its explanatory scope to a particular aspect of a broader, physical, phenomenon. He admitted that McDougall's proposals presented "an explanation for the transition from one antagonistic reflex to another" (Sherrington [1906] 1947, 200). As a framework for inhibition, however, they tended

to sever ... central nervous inhibition - of which I regard reciprocal innervation of antagonistic muscles as but one widely spread case - from other forms.... It appears to me unlikely that in their essential nature all forms of inhibition can be anything but one and the same process. (Sherrington [1906] 1947, 203)

Other forms of inhibition, a uniformly-caused function of nervous action, could not be explained by McDougall's scheme. McDougall's psychological insights were thereby re-cast in Integrative Action as contributions to the experimental study of physical (rather than mechanical) nervous function.

Though McDougall sought to forge an alliance with Sherrington, it is clear that his advances were not reciprocated. Sherrington adopted something of an institutionally hostile stance towards McDougall during the time both were in Oxford. For example, at the end of the First World War, Sherrington (now in the Waynflete chair) requisitioned the rooms in the Oxford Laboratory of Physiology that McDougall used for his psychological experimentation for more strictly physiological investigations. In 1920 McDougall left the department altogether to take up William James's old chair at the department of psychology at Harvard (Oldfield 1950,382). Though these events cannot unequivocally be identified with Sherrington alone, they reflected a commitment by him and many of his colleagues to the differentiation of physiological from

\footnotetext{
${ }^{19}$ I.e. "on any level." Letter from J.S. Burdon-Sanderson to C.S. Sherrington dated July 23 [1904] (Sir Charles Sherrington Fonds, 428).
} 
psychological endeavor (explored more fully in the second part of this paper). As will be seen, Sherrington's simultaneous appropriation of McDougall's conclusions and practical opposition to his investigations was only the most immediate attempt by him to limit the reach of ideas complementary to Bergson's holistic philosophy. In other areas of his work he would employ similar strategies that would hinder the reach and influence of figures sympathetic to Bergson's ideas who enjoyed far greater international recognition. Though he did not engage with Bergson's philosophy directly, Sherrington was a significant figure in the establishment of conditions within which Bergson's contentions regarding life and perception came to be understood as problematic. As will be shown, technical (rather than conceptual) cinematographic devices played a critical role in this process.

Finally, Sherrington's strategy of containing McDougall's psychological contentions within his own physiological schema threatened to severely limit the scope of his conclusions. Though he had established his reputation with detailed studies of simple forms of cell-based nervous function, his hope had been that such studies would eventually lead to an explanation of the function of nervous activity as a whole. Sensations could not for Sherrington be separated from the more general functions associated with nervous activity. These included not only visual, but auditory, olfactory, tactile, and visceral experiences and what Sherrington characterized as both simple "feelings" such as pain and pleasure, and complex "emotions" such as fear. It would be in this transition from explaining nerve activity to explaining affect and sensation that the psychological import of Sherrington's intellectual hostility to protoplasm-centered and otherwise vital conceptions of physiological psychology would have its most direct and visible effects.

\section{A Physiological Refutation of Bergson?}

The first part of this paper has shown how early twentieth-century physiology, exemplified by Sherrington, sought to contain vitalist contentions such as those in which Bergson invested. Bergson's contrast between a "cinematographic" mode of apprehension that centered on the conceptualization of living objects as mechanisms and his own conception of life in which the mind could become aware of its vital nature through intuition thus faced challenges from within physiology during the first decades of the twentieth century. Yet such developments cannot by themselves account for the decline of Bergson's scientific reputation. Rather, they constituted one aspect of a broader set of developments that, taken together, weakened Bergson's intellectual position overall. To arrive at a thorough understanding of the changing fortunes of Bergson's metaphysics it is necessary to consider the social and intellectual factors addressed in this part of the paper in conjunction with the technical and institutional changes that accompanied them. The second part will thus demonstrate ways in which Sherrington's attempt to employ inscriptive and stimulatory devices in 
support of his physical physiology contributed to the differentiation of physiological from psychological and philosophical modes of intellectual practice. It will outline the consequences for Bergson's philosophy of the adoption of technical epistemology, and demonstrate how it contributed to a more general growing sense of scepticism regarding the scientific plausibility of Bergson's claims.

\section{Part II. Physiology, Psychology, and the Un-Bergsonian Cinematograph}

\section{Introduction}

In the first part of this study, it was demonstrated that Bergson's characterization of physiological science as marked by two contrasting epistemic modes - that of a "cinematographic" mechanics of association on the one hand and an "intuitive" vitalism on the other - had begun to break down within physical physiology during the early twentieth century. Whilst the definition of nerve physiology as subject to physical rather than either mechanical or vital law might be portrayed as itself detrimental to the scientific plausibility of Bergson's thought, this second part of the study demonstrates that it was less the intellectual claims that physiologists and psychologists made, than the kinds of practices that they adopted, that had the greatest significance for Bergson's changing scientific fortunes. In particular, it shows that the increasingly technical (rather than mechanical) character of physiological endeavor at this time helped constitute a very different appreciation of the role that entities such as cinematographs played in intellectual practice than Bergson assumed. Appeal to the capacities of tools (and in particular tools that emerged from the cinema of attractions) as guarantors of scientific objectivity helped constitute conceptions of the body and perception that were quite different from those Bergson appealed to. For the physiologists and especially the psychologists of the 1920s, cinematographic devices had attained significance not only as means by which nature might be analyzed and re-constructed, but as themselves objects of concern.

\section{Inscriptions of Affect ${ }^{20}$}

As outlined in Part I, in positing vibratory bodily perception in opposition to what he characterized as "cinematographic" mechanical observation, Bergson was implicitly investing in a current of psycho-physiological science that had gained considerable traction during the final decades of the nineteenth century. Critically, as well as articulating a conception of life as adhering to different laws as those believed to govern non-living nature, this current of thought helped elevate a category (or rather

\footnotetext{
${ }^{20}$ https://cslide.medsci.ox.ac.uk/items/view/9711 (last accessed September 11,2017).
} 
set of categories) of psychological existence that had historically been conceived of as obstacles to thought (affective states) to the status of epistemic primacy. Thus, where previous thinkers had conceived of passions or emotions (on the transition between these categories, see Dixon 2003) as either problems to be overcome by observers or (as in the Kantian tradition) as aspects of experience to be balanced by rational comprehension, Bergson made them foundational to his philosophy. "Duration," Bergson claimed, could only be apprehended by attending to what he characterized as the vibratory conditions of existence. This existence moreover could not be perceived via the rational association of sensory effects: it must be "intuited" (e.g. Bergson, 1911 [1907], 176; Massey 2014). Further, given that the vibratory conditions of mental existence had their primary manifestation in organic life, it was to the philosopher's own body (rather than the external world) that intuition must initially be directed.

Bergson's insistence that philosophically-lived experience must be intuitive found its corollary in a similarly substantive strand of physiological psychology. The foremost advocate of this strand at the turn of the twentieth century was William James, Bergson's correspondent and principal ally in the English speaking world. James and Bergson found particular cause for mutual admiration in their respective conceptions of the status of affective or otherwise non-rational (for Bergson intuitive, for James emotional) states in perception. However, James found a range of physiologic and psychologic voices (Sherrington's not least among them) ranged against him at the end of the nineteenth century. Since Sherrington and his physiological colleagues' opposition to James's conception of emotion played an important part in the more general retreat from scientific respectability of views complimentary to Bergson's, it is necessary to examine it before moving on to consider the significance of Sherrington's cinematograph studies themselves. As Otniel Dror $(1999 b ; 2011)$ has shown, the relative prominence of different representational techniques in studies of emotion had direct relevance for the sorts of claims that they carried. Sherrington's technical epistemic commitments, this section demonstrates, helped foster an approach to the study of emotions that not only cast doubt on the scientific claims that Bergson invested in, but precluded the possibility that intuition might present a means by which the nature of vital existence could be accessed at all.

The vital body played a critical role in James's understanding of emotion. In a phrase that had strong parallels with Bergson's protoplasmic conception of life, James referred to the body as a "sounding board" through which emotions were conveyed and experienced (Wassmann 2014, 173-174; see also Deigh 2014). Announcing what he characterized a self-generated "revolution" in the investigation of emotion, he argued that it was not (as associationists had presumed) sensations of the external world that had the greatest salience for psychological experience. Rather, apprehension of the world outside of the body was intimately bound up with, and indeed characterized by, that of its inside. Emotions, James claimed, were in fact themselves kinds of sensation. What differentiated them from the more familiar touch, sight, sound, taste, and smell was not 
their function in the psyche, but rather the world to which they were directed: where the traditional sensations represented information gathered from the surrounding environment, emotions constituted information gathered from the visceral changes of the body. Emotions were nothing more than vital bodily changes apprehended by the individual.

James's publications on emotion challenged two claims that had found prominence amongst associationist physiological psychologists during the latter half of the nineteenth century. The first of these was that it was possible to apprehend one's own body using similar means as those employed to sense the external world without disrupting the functioning of the rational mind. Drawing on French physiological studies of the early nineteenth century, British physiological psychologists including Spencer and Bain had suggested during the 1860s that experience was not simply the consequence of external perception, but was rather built up from a more fundamental source, which they termed "muscle sense" (Smith 2011). Closely associated with physical movement of the body, this sense was conceived of as entirely separate from what were characterized as the more complex states of thought and emotion. Though gained from both the inside and outside of the body, perceptual experience, for these psychologists, could be entirely explained by reference to the conjunction of the sense-impressions that Bergson found so problematic. James, in contrast, argued that even the experience of external reality was inevitably colored by the emotional apprehensions presented by the viscera (James 1884; 1894, 523-524). Secondly (and more explicitly), James challenged the physiological psychological claim that emotions could be identified with a specific part or region of the body or nervous system. Though Wundt for example accorded a greater role to emotion in the perceptual process than either Spencer or Bain, he had like them contended that it was primarily a property of the brain. Emotions (Gefühl) for Wundt were not simply reports of the vital situation of the body, as James claimed, but in fact caused change within it. Emotions in this latter sense could be a means by which the body became passive to the nervous mind, and controlled by it (Wassmann 2014, 169-171; Wassmann 2009). For James in contrast, emotions were the bodily accompaniment of external sensation, and as such constituted an active component of perception itself.

There can be little wonder then that both James and Bergson found the claims made by the other so appealing (see e.g. Loerzer 2014). James, like Bergson, accorded affective and non-rational states a foundational role in perception. Both portrayed the vital body in terms of vibratory resonances with their surroundings. Both found the claims made for sensory association problematic. And both sought to put in their place a conception of mind in which the affective body enjoyed far greater psychological prominence than it had hitherto. Where Bergson appealed to intuition, James advocated emotional sensation. Both concepts suggested that the only means by which bodily nature could be apprehended without disturbing its nature were ultimately dependent on the experiencing subject (Carroy and Schmidgen 2002, 5 and 13). Bergson and James 
prominently proclaimed their mutual admiration, with James devoting lectures to Bergson, and Bergson writing the preface to the French translation of Pragmatism ${ }^{21}$ in 1911.

That Sherrington was, during the first decades of the twentieth century, recognized as having published one of the most incisive studies to cast doubt on the scientific plausibility of James's theories (Wassmann 2014, 178-179) can therefore be read as having significance beyond the immediate claims that it made concerning James himself. In publishing two articles (which appeared in 1900), and repeating their conclusions in Integrative Action, Sherrington positioned himself as an important and increasingly influential antagonist of some of the more strident claims being made for affective states as a necessary condition and generative source of apprehension (Dror 1999a, 214-215). This is not to say that Sherrington sought to deny emotion a role in the investigative process: indeed, as an author of both poetry and prose he appears to have considered it of great importance. Rather, it is to note that he placed strict limits on the role that it (and by implication instinct and intuition) could play in scientific investigation (Smith 2000, 304). Though emotion might have been appropriate within self-expressive genres and disciplines, Sherrington's highly technical scientific publications convey little affective input.

Significantly, Sherrington's initial physiological study of emotion drew primarily not (as did Bergson and James' works) on the artistic and literary traditions through which affect had conventionally been considered, but rather on recently established practices of physiological representation. As Dror highlights, studies such as Bergson and James's drew on long-established investigative practices that "framed observation around the embodied-experiential reactions of observers" (Dror 2011,327). In contrast, the strand of physiological psychology to which Sherrington sought to contribute approached emotion as something that could be made visible via the application of tools to bodies. Though they for the most part remained wedded to categories of psychological analysis established within philosophy, physiologists working in the midto-late nineteenth century such as Duchenne de Bolougne, Angelo Mosso, and Paolo Mantegazza sought to capture emotions by recording them, thereby making them apprehensible to communities of observers rather than the experiential subject alone.

Notably, the visualization tool to which Sherrington appealed was concerned neither with Wundtian attempts to measure the temporal nature of conscious experience, nor the mapping of a specific region or organ of the body, but with the delineation of spatial change at a single point within it over time. Perhaps unsurprisingly given his training, Sherrington utilized a piece of equipment that was foundational to the disciplinary conduct of physiology (Brain and Wise 1994; de Chadarevian 1993). Moreover, this tool was not (at least directly) implicated in Bergson's critique of scientific recording (Brain 2015,32-33). The kymograph, with its body-sensitive needle point resting on a rotating drum of soot or paper, was the emblematic physiological

\footnotetext{
${ }^{21}$ https://cslide.medsci.ox.ac.uk/items/view/9729 (last accessed September 11, 2017).
} 
tool of the late nineteenth century. Notably, it constituted exactly the inverse relation between space and time than the cinematograph as characterized by Bergson. Bergson emphasized in Creative Evolution that the cinematographic sense of reality depended on the successive juxtaposition of images that represented effectively non-existent points in time (Bergson [1907] 1911, 304-308). In stark contrast, kymographic traces cast space, rather than time, as reducible to an effectively non-existent point. Thus whereas the successive photographic and pictorial representations such as those of Duchenne and Mantegazza appeared (deceptively according to Bergson) to capture outward expressions in their visual entirety (Moruno 2016, esp. 150-154; Rees, 2014), kymographs charted the vibratory fluctuations of single bodily points along extended uninterrupted temporal paths. Ideally singular spatial points were taken in kymographic studies as indexes of the broader physiological functioning of the body. Thus Claude Bernard identified the heartbeat as the index of bodily emotional expression (Dror 2011,337). Though later studies sought to combine a range of bodily processes including blood pressure, electrical resistance of the skin, and respiration into a composite physiological picture (Dror 2006, 135), the fact remained that however overlaid, every kymographic recording that was produced assumed a single, ideally minute point in space from which a reading could be taken.

Sherrington's emotion studies centered on only a single kymographic recording: that of the changing pressure of the femoral artery of a dog that he had vivisected whilst a visitor to Mosso's laboratory (Dror 1999a, 215-216). The single line traced across the page, a comparatively flat set of undulations interrupted by a dramatic increase in magnitude in their center, showed what Sherrington claimed to be direct evidence that emotions were not psychological representations of bodily conditions at all. Rather, Sherrington contended that emotions (which he defined as "feelings ... excited not by a simple unelaborated sensation, but by a group or train of ideas") played an active role in the production of bodily effects (Sherrington 1900, 328; cf. Dror 2006, 129-130).

In the course of investigating the "scratch" reflex in a dog, Sherrington had cut the efferent nerves from its body to the brain, thereby preventing any communication by the former reaching the latter. Preparing to apply a current to a hind leg of the animal, he had turned to test the electrical equipment that he was using. This made a whirring sound. Upon returning to the animal, he reported, he had noticed that its blood pressure had increased dramatically (represented by a large increase in magnitude on the kymographic trace). After a few attempts to ameliorate this increase prior to testing, Sherrington had come to the conclusion that it was the whirring sound of the equipment, rather than any deliberate intervention, that was causing the disturbance. Remembering that he had previously used this animal as a test subject for evaluating the limits at which anaesthesia remained effective (a procedure that would necessarily have caused the animal considerable discomfort), Sherrington concluded that it was the dog's recollection that the whirring was followed by the experience of pain that was causing the blood pressure increase: the memory of pain was making it afraid (Sherrington 1899-1900, 393-396). But how, Sherrington asked, could this dog, insensitive to its 
own body as he presumed it to be, have experienced fear if emotions were in any sense representations of bodily sensations?

Sherrington's study had both normative and epistemic influence on subsequent physiological investigations relating to affect. In presenting his studies, he had related a further set of experiments on "spinal" dogs (i.e., dogs which had had the nerves communicating from the body to the brain severed), in which he drew inferences regarding their emotional states from their behaviors in his Liverpool laboratory (Sherrington, 1899-1900, 396-403). Taken together, he contended, these studies precluded the possibility that "higher" emotions could be associated with anything other than cerebral processes. Whether or not the experience of emotion preceded the cerebral change, or the two were concomitant, it seemed clear to him that they were phenomena that did not proceed from an originally noncerebral (i.e., visceral) change (Sherrington 1900, 330; Sherrington [1906] 1947, 256-269). Physiologists working after 1900 not only took this assertion as their point of investigative departure, but accorded epistemic primacy to the equipment to which Sherrington had appealed. Thus James's Harvard colleague Walter B. Cannon's Bodily Changes in Pain Hunger Fear and Rage $e^{22}$ (1915), a publication that set the tone for subsequent physiological work in the field, relied on kymographic recordings almost to the exclusion of other forms of evidence. This work re-affirmed Sherrington's contention regarding the continuation of emotional expression following the dissociation of the brain from the body. Further, it compounded objections to James's theory: quite different emotions, Cannon contended, produce physiologically similar effects; the physiological processes that accompanied emotional experience did not act quickly enough to provide "sensory" information; and even when such visceral changes did in fact take place, the relevant emotion was not according to Cannon necessarily experienced (Wassmann 2014, 179-180; see also Dror 2014). Kymographic recording thus became the principal means by which physiologists sought to define the relations of emotions to bodily processes. Emotion could not for these practitioners itself function as a means of apprehending nature (by for example providing clues to the nature of vital rhythmicity), but appeared rather as a psychological object capable of causing physiological effects.

Kymographic studies can thereby be understood as contributing to the replacement of the broad-ranging academic discussions of emotions and passions of the nineteenth century with the narrow, highly-focused contributions of a small community of recognized physiological and psychological specialists during the twentieth. Whilst the study of the relations of emotions to bodily processes was in Sherrington's view one of the "points where physiology and psychology touch" (Sherrington [1906] 1947, 257), the place of introspection in these fields was less certain. Sherrington spoke for many physiologists when he noted that in discussion of the results of

\footnotetext{
${ }^{22}$ https://cslide.medsci.ox.ac.uk/items/view/9739 (last accessed September 11, 2017).
} 
experiments on emotion involving the manipulation of animals' nervous systems "we are ... hopelessly cut off from introspective help" (Sherrington 1900, 330). Psychologists and psychiatric practitioners of course experienced a far more ambiguous relation to introspection and indeed intuition as investigative modes. But even here discussion decreasingly focused on the personal experience of those who instigated lines of inquiry, and increasingly appealed to self-reports of experiment participants who had been selected for their observational acuity, alongside technical recording or measurement of bodily response (e.g., Engstrom 2003, chap. 5; Green 2010; Young 2015). Investigators working in the growing number of laboratories devoted explicitly to experimental psychology appealed to tools such as the Hipp chronoscope and various forms of tachistoscope to legitimate their claims to be conducting scientifically rigorous investigations (Carroy and Schmidgen 2002, 6-11, 19-20, 26; Benschop 1998). The increasingly prevalent epistemic ideal of producing recordable and therefore (it seemed) verifiable psychological effects can thus be considered as part of the same historical phenomenon in which kymographic recording came to be understood as the principal means by which the relevance of emotional to visceral nature might be understood (Daston and Galison 2007, esp. 168-171, 183-187; Green 2010).

Within physiology, and for many psychological investigators during the early twentieth century then, emotion became a field of study in which particular techniques of representation and observation came to be lauded over the introspective or intuitive conclusions of individual observers. Use of kymographs and other recording and measuring tools including chronoscopes and tachistoscopes became emblematic of a set of investigative commitments that precluded the possibility that knowledge might be grounded first and foremost in personal experience. Not only the specific claims that James and Bergson made regarding the apprehension of bodily nature, but the very form of evidence that they appealed to in their discussions of emotion had by the 1920s begun to be understood as scientifically suspect. In opposing a specifically intuition-derived duration to a spatializing cinematographic mode of intellectual conduct, Bergson had invested in a conception of psychology as a practice that was capable of speaking directly to the physiological nature that underpinned it. Similarly, James's conception of emotions implied that their experience could provide clues to visceral nature. Sherrington's studies of emotion refused this capacity of psychological study, and appealed to the experimental evidence of graphic inscription to directly contradict James's claims. In so doing, they put in their place a conception of two complementary fields that "touched" at particular "points" and shared epistemic commitments, but nevertheless addressed distinct objects. Thus James and Bergson were confronted not with a critique based on one or another specific claim regarding emotion, but an assumption regarding the limits (ideal if not always enforced: see Dror 2006, 135-136) of disciplinary explanation. Visceral activity might be caused by emotions emanating from the brain, but the study of viscera could not reveal anything regarding the nature of emotions themselves. Similarly, the study of emotion as a psychological category did not in itself reveal anything of the nature of bodily processes. Instead, physiologists were to limit themselves to a 
strictly technical study of organic responses: a circumstance in which cinematographic equipment, but not Bergson's vital alternative to his cinematographic mechanism, could be accorded epistemic weight. We are now finally then in a position to address Sherrington's cinematograph studies and their significance for Bergson's claims.

\section{The Cinematographic Physiology of Sensation ${ }^{23}$}

In Integrative Action, Sherrington introduced his cinematograph studies as a response to the question of whether or not it was possible to extend his conclusions regarding nervous activity in simple reflexes and more complex emotions to the study of sensations. For the majority of the book, he had supposed the animal to be "a puppet without passions, memory, feelings, sensations, let alone ideas concrete or abstract." Now, in his final chapter, he queried whether "we [can] at all compare with the simultaneous co-ordination of the nervous factors in a motor reflex the synthesis of the nervous elements whose combination underlies a simple sense-perception?" (Sherrington [1906] 1947, 353, 355). Though he notably did not go so far as to make any positive claim, he intimated that the "most complex" psychological phenomena might be explained by reference to his physical interpretation of nervous action. ${ }^{24}$ Less clear from Sherrington's text, however, is that were such a claim to have been established, it would have turned back a tide of opinion that had been gaining ground in physiology since at least the middle of the nineteenth century.

It was no coincidence that Bergson's British supporter McDougall had arrived at his conclusions following a close engagement with German physiological psychological research practices. By the middle decades of the nineteenth century, the combined influence of Kant and Naturphilosophie on German scholarship had encouraged an intimate relation to emerge there between the study of the senses through the generation of illusion, and debates surrounding physical and vital explanations of physiological function (Schickore 2006, esp. 385-391; Friedman and Nordmann 2006; Leary 1982). Most prominently, Hermann von Helmholtz had argued that the perception of nature ultimately depended on an act of judgment that could not be understood in terms of bodily activities. The living body, as the Helmholtz of the 1860s conceived it, was a physical structure the behavior of which could be characterized in terms of mathematical laws. As such, it constituted a medium through which impulses from the external world were conveyed to the mind. Whilst nerves were conveyors of sensory stimulations, it was the function of a physiologically-inaccessible mind to arrive at judgments regarding nature. Mind and sense organs thereby constituted two entirely distinct elements of the perceptual process (Lenoir 1993,123-125; Turner 1994,73-80).

\footnotetext{
${ }^{23}$ https://cslide.medsci.ox.ac.uk/items/view/8794 (last accessed September 11, 2017).

${ }^{24}$ For an account of Sherrington's conception of sensation as it emerged later in his career, see Smith 2001a, $232-235$.
} 
Helmholtz's sensory model had not gone unopposed however. Starting in 1863, Hering had waged a lengthy campaign against any separate consideration of sensations and sense-organs themselves. Hering and his supporters drew on a longerestablished tradition of psycho-physiological research to develop a sophisticated set of demonstrations and arguments identifying visual illusions not with the inaccurate judgments of a physiologically-independent mind, but with the physiological makeup of the organs of sense (Turner 1994, 89-93). As already noted, Hering thereby came to characterize sensation as the product of autonomously-acting organic forces that had only oblique relation to any bodily-independent judgment. This, along with the British tradition of optics, was the principal intellectual condition in relation to which the cinema of attractions took shape during the final decades of the nineteenth century.

One of the principal means by which Helmholtz, Hering, and their various supporters and detractors conducted their disputes was via the creation and demonstration of a vast array of illusion-generating devices (Wade 2005, esp. 126-131). Though they differed profoundly as to their conclusions, all participants understood these as the epistemic means by which relations between life and sensation could be established. Müller's Göttingen laboratory had been well stocked with equipment developed for the study of color vision via illusion, and Münsterberg's wide range of devices for sensory and particularly visual experimentation at Freiburg has already been referred to (McDougall 1961, 204-205; Schmidgen 2008). In acquiring Münsterberg's psychological laboratory, Sully had helped bring a set of research questions to Britain that had hitherto generally only appeared in the country in terms of broader enquiries concerning the relation of matter to spirit (for example in the study of Mesmerism, or, as frequently, optics) (Hayward 2007, 40-56; Schickore 2006, 396-401). The tools that Münsterberg's laboratory contained invited investigation of sensory and more generally psychological problems within a very different setting than these latter sciences. For example, Richet, Binet, Bergson, James, and such colleagues of Sherrington's as McDougall, Cyril Burt, and the physicist Oliver Lodge found common ground in their belief that spiritualist phenomena constituted an epistemologically significant site of analysis (Valentine 2012). Physiological psychologists sympathetic to the aims (if not always the specific claims or techniques) of Wundt's "psycho-physics" on the other hand, including Théodule Ribot, Müller, Münsterberg, and Sherrington, as well as later investigators such as Max Wertheimer, invested far more heavily in the technical production of visual effects. For these latter figures, the apparent embodiment of vital capacities in living individuals remained epistemologically secondary to the quantifiable (or at least recordable) effects of controlled stimulation of living bodies. This technical emphasis was often accompanied by skepticism regarding the exceptionality of vital substances or effects from physical laws more generally.

It is not surprising then that Sherrington's initial foray into the study of visual sensations, published in 1897, relied on an illusion-generating device in the shape of a multi-colored disc that could be rotated to produce the sensation of a single 
color. This suggested a direct parallel between two phenomena that had been current amongst philosophers of optics since the eighteenth century (Wade 2005, 112-116; Mannoni [1994] 2000, 204-212). These were studies relating on the one hand to the shortest time that an eye could be exposed to a flash of light and an associated lightsensation be experienced, and on the other to the production of a sense of continuous experience via repeated exposure to radically different visual stimuli. Regarding the first of these, eighteenth- and especially nineteenth-century natural philosophers had come to concern themselves with a wide range of phenomena that occurred over very short intervals of time. The nature of sparks, bubbles, and vibrations (to give three amongst many possible examples) were interrogated using tools designed for the visual "fixing" of transient phenomena (Ramalingam 2015; Canales 2009, chap. 5; Schaffer 2004, esp. 170-177). Within the German context especially, a set of physiological problems associated with these phenomena had emerged that considered the processes by which stimulation of eyes actually resulted in visual experience (Schickore 2006, 123-126). One particularly prominent theme was the fact, embodied by the motionsensation-generating phenakistoscope (and later Muybridge's zoopraxiscope), that a series of short stimulations could, through the phenomena of "persistence of vision," create an illusion of temporal continuity (Mannoni [1994] 2000, 213-222). In 1885, Marey's associate Adolph-Moïse Bloch adapted a version of the intermittently-obscured lamps that William Henry Fox Talbot and Simon von Stampfer had developed during the 1830 s to physiological investigation. Where Talbot aimed to measure light intensity itself, Bloch sought to establish a law regarding the rates at which individual sensationflashes produced a continuous light-sensation under different conditions (Bloch 1885, 493-495; Schickore 2006, 254-255). Such studies prompted a range of physiological investigations into Stampfer's “stroboscopic" effects during the 1890s (e.g. Charpentier 1890; Schenck 1896; Marbe 1898).

Sherrington's 1897 paper however dealt primarily with a parallel set of investigations into the "fusion" not of light-, but of color-sensations. Building on the optical studies of color by Talbot, Thomas Young, James Clerk Maxwell, Thomas Sutton and others, the physicist Ogden Rood had in 1893 presented what he considered a method by which colors might be differentiated according to their "reflecting power." Spinning a circular disc on which alternating bands of light and shade had been painted, Rood measured the rate of rotation required to eliminate the sense of intermingling or "flicker" between them (Rood 1893; for context, see Ramalingam 2013, 252-257; Cat 2013). Exposing observers to intermittently contrasting stimuli created sensory effects not present when equipment was at rest. Sensation was increasingly coming to be addressed not in terms of phenomena of spatial differentiation, but rather in relation to questions regarding temporal continuity (Crary 1999, 127-148). The phenomena studied by Sherrington the physiological conditions pertaining to the production of light- and color-sensation - thus came together (or rather were re-connected) via a set of experiments that had been foundational for the emergence of illusion generation as a mode of laboratory investigation. 
Despite the relative paucity of illusion experiments amongst British physiologists compared to their German counterparts at this time, Sherrington's colleagues did experiment with illusions of temporal continuity. Shortly after Sherrington's initial flicker study came out, his Cambridge compatriot Otto Fritz Frankeau Grünbaum published a two-part paper in the Journal of Physiology (Grünbaum 1897-1898). This study, which also addressed the rate at which alternating stimuli fused into continuous perception, strove for far greater precision than had Sherrington. Rather than direct both eyes to an external stimulus in the shape of a rotating disc, Grübaum created an experimental device that could project two separate beams of light onto the retina of a single eye (see fig. 3). One of these beams was constant, thus constituting a point of comparison. The other however was interrupted by a disc with angular segments cut out of it. By rotating this disc at different speeds, and recording the speed of rotation when the brightness of the two beams became indistinguishable, Grünbaum sought to arrive at a more accurate estimation of the rates of exposure necessary for the experiences of different brightness. The parallels between the establishment of illusiongenerating devices within physiology laboratories and that of cinematography more generally are prominent here. One of the key elements of cinematographic devices and one of the most difficult pieces to co-ordinate with the movement of celluloid film-strips - was a disc or "shutter" (similar to the ones Talbot and von Stampfer had developed) that cut off the projection of light at intervals proportional to the replacement of images on the projector. The minimal rate at which cinematographic images had to be replaced and exposed to view was determined by the rate at which images could be perceived as individual, rather than a continuous moving picture, i.e. by the phenomena of persistence of vision. By the late $1890 \mathrm{~s}$, then, it is possible to detect a convergence between the laboratory devices that emerged in conjunction with the cinema of attractions, and tools that would come to be recognized as "cinematographic" in Bergson's sense of the word. During this decade, the physiological study of the persistence of vision and the construction of ever more complex illusiongenerating devices went hand in hand, and became decreasingly differentiable from the cinematographs that we associate with the period today.

By 1902, Sherrington had begun to develop a device that was cinematographic in this above-described sense. This device both surpassed Grünbaum's in experimental precision, and anticipated many of the features that Bergson would deploy in his idealized device. ${ }^{25}$ Crucially, in addition to constituting a means by which the temporal phenomenon of visual flicker could be studied, Sherrington's experiment also incorporated a means of producing spatially differentiated experience. Sherrington's experiment placed an incandescent lamp (such as might be used in a projecting device) in the middle of a rotating cylindrical screen, into which three rows of rectangular windows had been cut (see fig. 4). Surrounding this cylinder was a casing, with a

\footnotetext{
${ }^{25}$ Sherrington's device is still in existence. It is currently held at the Department for Physiology, Anatomy and Genetics, University of Oxford.
} 


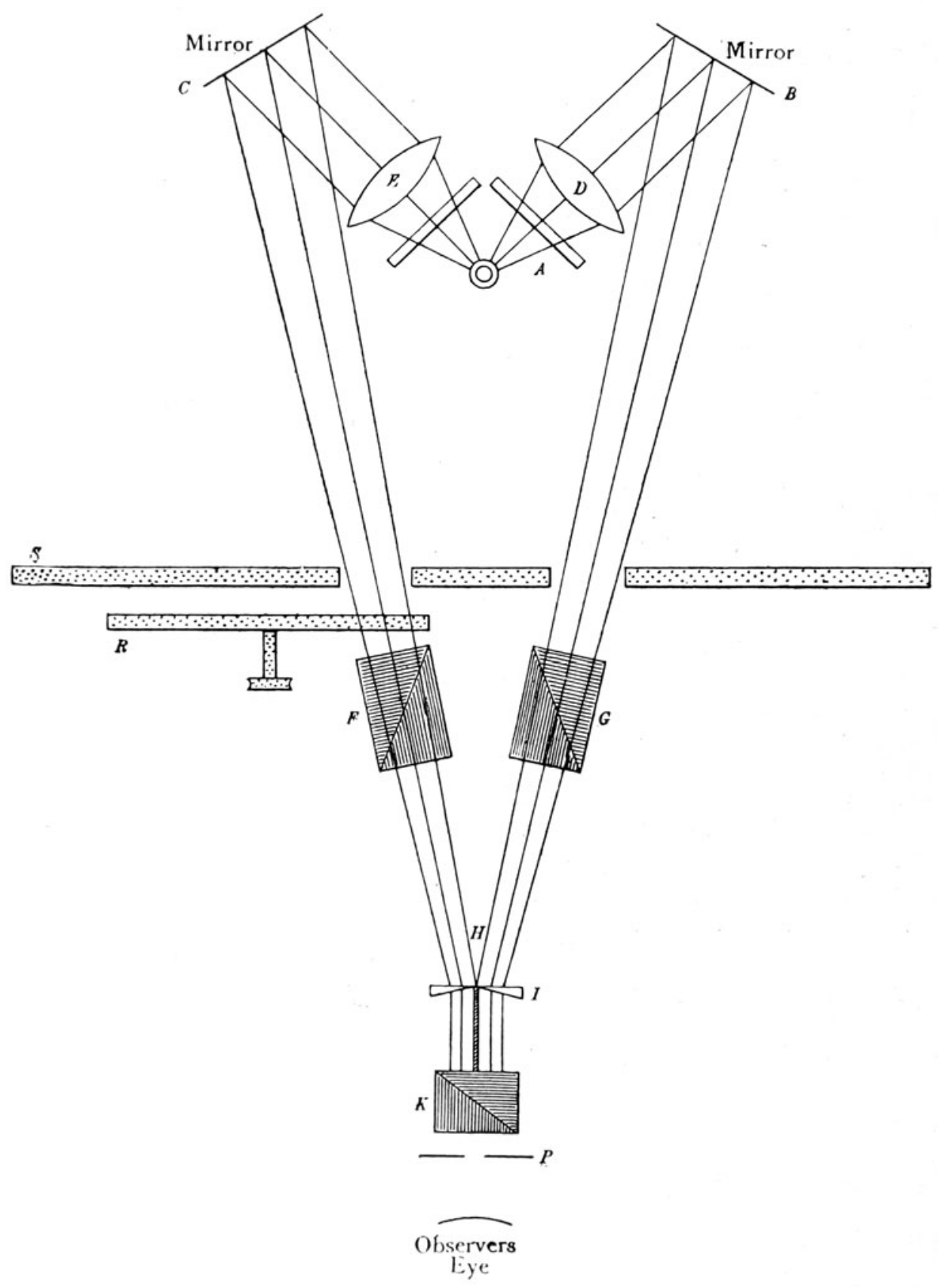

Fig. 3. From Grünbaum 1898. 


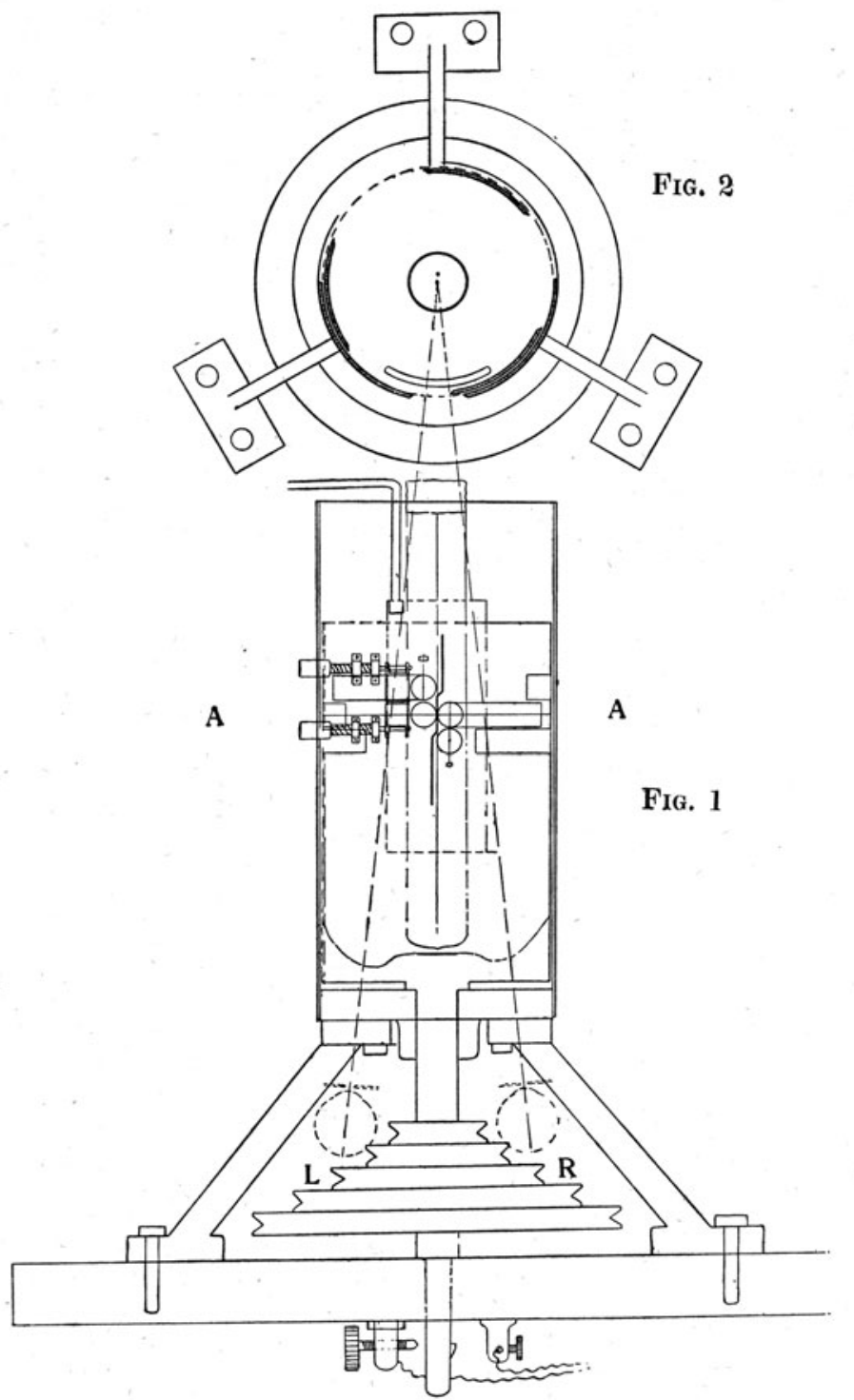

Rotating Lantern. Fig. 1. Elevation, seen from front. Fig. 2. Horizontal plan, through level of A-A, Fig. 1. Supports seen in perspective. The eyeballs, pupil screens, and convergent visual axes are indicated belonging to Fig. 2, but carried through Fig. 1. The plan of the lantern is given one-third actual size. Description in text.

Fig. 4. "Rotating Lantern,” from Sherrington 1904. 
further four small holes cut in a step formation on its side. As the inner cylinder turned, thin beams of light were intermittently projected through these holes (Sherrington 1904, 27-30). Just as in Grünbaum's study, the rate at which light was projected could be varied and the rotation rates at which the sensation of flicker appeared and disappeared ascertained. But Sherrington sought even greater accuracy than had Grünbaum. By making the holes through which light passed very small, he sought to confine the optical effects produced to as few nerves and as small an area of the retina as possible. The constancy of the rotation rate of the device was ensured through utilization of a motor such as that which During notes was central to Bergson's conceptualization (During 2015). Moreover, by positioning the experimental subject at a carefully calculated distance from the lamp, and providing them with correcting lenses, the holes on each side would project light onto an optically "equivalent" point on each retina. Whereas Grünbaum's device had exposed different halves of one retina to different rates of stimulation, Sherrington's could (by varying the size of the rectangles cut into the cylindrical screen) expose the "corresponding" points of both retinas to the same (Sherrington 1904, 31). Since the 1860s, physiologists had debated different propositions regarding the combination of retinal sensations into a single experience of vision (Turner 1994, esp. 41-48, 58-60, 162-168; Banks 2001). Sherrington's device put these spatially-oriented concerns into contact with the related but hitherto largely separate debate regarding the persistence of vision (i.e. the production of experiences of temporal continuity).

Sherrington brought all of the resources that Daston and Galison associate with "mechanical objectivity" to bear in conducting his cinematographic experiment (Daston and Galison 2007, 138-161). Observers were provided with an electronic key that, when pressed, would (again recalling During's Bergson) mark a motordriven myograph cylinder, on which the rate of rotation of the screen at that point was recorded. Even more strikingly, Sherrington went to great lengths to ensure that observers remained as passive as possible to the phenomena that they experienced. Seated in a "dark compartment" screened off from the experimental set-up, the subject was made to "give his sole attention to the watching of the illuminated discs." Once the beams of light had been corrected by the lenses, the interruption of further light sources as well as changes in retina size were ameliorated by the introduction of "artificial pupils" between the lenses and the eye. The propensity of some observers to move their head when they closed one or another eyelid was eliminated by the utilization of "blackened aluminium side-flaps" that could be secured in place as needed. Finally, "fixation of the observer's head was secured by a solidly made wooden rest, supporting adjustable chin and forehead pieces" (Sherrington 1904, 29-30). The passivity of subjects to the stimulating device was thereby, it seemed, ensured.

Even before Bergson had published his idealized conception of the cinematograph in its fully articulated form, Sherrington had begun to bring the production of cinematographic effects of continuity within the purview of his physical physiological schema. His goal was not merely to arrive at an accurate estimation of the rate at 
which flickering sensations transformed into continuous ones, but also to interrogate the relationship between the retina, the nerves, and visual sensations more generally. Hering's studies had suggested that the optic nerves had to connect before they arrived at the center of consciousness, as it was in the eyes and their associated nerves that vision was produced. Helmholtz's insistence that knowledge was a judgmental construct, in contrast, seemed to imply that all sensory organs were connected with the cerebrum individually - it was only through the mind bringing individual sense-experiences together that external perception was generated. By creating a situation in which "corresponding" points on the retina could be stimulated in similar but crucially alterable ways, Sherrington sought to establish the modes of interaction between visual fields with greater confidence than had these physiological psychologists. His cinematographic device was deployed as a guarantor of observational consistency - an issue that was notoriously problematic for physiological psychologists who appealed to the evidence of their own sensory experiences (Turner 1994, 59-60). By blocking off some of the holes and one or another of the rectangles cut into the rotating screen, it was possible to create situations in which retinal points could be stimulated either simultaneously or alternately, but always at the same rate. Thus, Sherrington hoped, it would be possible to examine whether stimulatory effects were "additive" between corresponding nerves, or whether contentions regarding their "mutual inhibition" were in fact accurate (e.g. McDougall 1901b; Sherrington [1906] 1947, 375-378). If binocular visual sensation could be shown to be additive, Helmholtz's conclusions could be confirmed. If they inhibited one another, Hering would be supported. Here then appeared a crucial test of a long-standing dispute within physiological psychology.

Despite the lengths to which Sherrington went to ensure that both his subjects and his objects were as carefully arranged and closely controlled as possible, however, he was unable to reach any firm conclusions regarding his results. Sherrington's aim had been to evaluate the extent to which his conclusions regarding the physical nature of simple reflex action could be brought to bear on the interpretation of complex sensory phenomena. But when it came to drawing conclusions from these studies, he himself wavered between the two above-noted possibilities. The problem was not - as had hampered so many prior studies in this vein - disagreement amongst individuals, as experimental conditions seemed to have ensured agreement between subjects. Rather, it concerned the seemingly contradictory nature of the results themselves. Whether retinal stimulations could be said to sum together or mutually interfere depended, it seemed, on the mode of stimulation. In a statement that had direct relevance to the Einstein-Bergson debate, and to which Piéron would gesture in his final remarks there, Sherrington perplexedly concluded that "corresponding retino-cerebral points retain individuality as regards time-relations ... [but are] completely confluent by reference to visual space" (Sherrington [1906] 1947, 366). Furthermore, the "rule of combination" revealed by the experiment "finds little solution by appeal to summation or interference of retinal and purely physiological processes" (Sherrington [1906] 1947, 
369). Though Sherrington leant towards a Helmholtzian conception of visual sensation, technically mediated investigation of sensory experience, even when conducted under carefully controlled laboratory conditions, did not lead to clear-cut physiological conclusions.

The possibility that the study of visual illusion could inform study of the extent to which optic nerves actively contributed to sensation had taken Sherrington a long way from his starting point of the physical interaction of individual nerves. Integrative Action continued to portray the study of "sensual reaction" as at least potentially part and parcel of that of nerve reactions more generally. Although the difficulty of interpreting the binocular flicker experiment showed that "hasty conclusions" regarding the parallels between simple and "sensual" reflexes were unwise, it was nevertheless possible to insist on a "likeness of nervous reactions expressed by muscular and other effector-organs to reactions whose evidence is sensual" (Sherrington [1906] 1947, 384). More generally, the correspondence of sensations to positions in space, to which the body could direct its actions, indicated that "physiology and psychology, instead of prosecuting their studies ... more strictly apart ... will find it serviceable for each to give the results achieved by the other even closer heed than has been customary hitherto" (Sherrington [1906] 1947, 385). Nevertheless, the failure of Sherrington's cinematograph study to support claims regarding the physiological conditions of vision did not recommend the device for physiological investigation more generally. Sherrington's study in many ways marks the point at which the physiological study of optics and the psychological study of vision began to go separate ways.

Though Sherrington's cinematograph studies were not a success in his own (physiological) terms, and he would not produce any further work in this vein, they did confirm to him that sensory experimentation was irrelevant to physiological investigation. Just as the utilization of kymographs helped construct a specifically physiological (rather than physiological psychological) approach to the study of emotion, Sherrington's cinematograph experiment helped define the limits of physiological vis-a-vis psychological investigation. In subsequent years, Sherrington, as head of the Oxford Laboratory of Physiology and an increasingly lauded figure amongst his fellow physiologists, would use his position to promote a physiology and psychology as complementary but nevertheless disciplinarily distinct endeavors. Though tools such as the myograph and cinematograph would play significant roles in both fields of study (the latter for example being utilized in both the representation of nerves and the production of sensory effects) they would come to be directed to distinct problems in each. ${ }^{26}$ Physiology and psychology would share a decreasing number of conceptual problems and definitional terms as the twentieth century progressed.

\footnotetext{
${ }^{26}$ See for example Fearing [1930] 1970, 286-310, on differentiation between physiological and psychological discussions of the reflex.
} 


\section{Experimentation and Disciplinarity: Assimilating Bergson ${ }^{27}$}

That Sherrington ended his scientific engagement with experimental devices designed to produce sensory effects around 1906 should not be taken as evidence that cinematographs themselves had decreasing significance for physiological practitioners during the first two decades of the twentieth century. As Hannah Landecker and others have shown, it was for their recording and representational rather than their stimulatory capacities that these tools were most prominently adopted within physiology. During the first decades of the twentieth century, cinematographic recording was frequently deployed in attempts to inscribe and represent the motile aspects of life. Such interests were accompanied by further innovations in cinematographic tools themselves. For example, at the Institut Marey, Charles-Émile François-Franck and Lucien Bull developed a means of recording and projecting living nature in three dimensions, and adapted celluloid film for the creation of highly sensitive myographic equipment (Bull 1910; Cartwright 1995, 40-46). During the 1920s, Sherrington and the group of his students and colleagues associated with the Oxford laboratory of physiology would adapt these latter tools to their "optical myograph" studies of minute muscle movements (Sherrington 1921, 245-246). Such studies constituted a re-assertion of the representational (Bergson's "cinematographic") over the stimulatory possibilities that illusion-generating devices afforded. This also entailed the adoption of representation-centered modes of investigation even where such tools invited novel forms of sensory testing. Thus during the 1920s, physiological engagement with radio transmission and reception devices was largely confined to their adaptation for recording purposes rather than any sensory effects that they might have had (Garson 2015).

By the 1920s, the questions that motivated physiological psychological studies of illusion had mutated into more disciplinarily specific concerns. Where physiologists utilized cinematograph-like devices to represent the movements of life, psychologists concerned themselves more intensely with their potential as a source of visual effects. Mitchell Ash thus notes the significance of a tachistoscopic device designed to produce sensations of movement (the experiential example that Bergson had put forward as beyond the purview of associationist/mechanistic perception) in a controlled, recordable manner for the establishment of laboratory-centered psychology in Weimar Germany. As Ash highlights, tachistoscopic studies by such figures as Wertheimer marked the culmination of long-standing trends within German academies, in which psychology began to emerge as a discipline that was independent from both philosophy and physiology (Ash 1995, esp. 125-129, 203-218). Beginning in 1910, Wertheimer had contended that sensation could not be studied by reference to individually isolatable sense-impressions, but was rather apprehensible only in terms

\footnotetext{
${ }^{27}$ https://cslide.medsci.ox.ac.uk/items/view/8796 (last accessed September 11, 2017).
} 
of an immediately perceptible whole or "Gestalt." Wertheimer's collaborators Kurt Koffka and Wolfgang Köhler invited their students to engage with Bergson in their seminars. But it was in the laboratory that the latter's critique of associationism had its greatest influence. "Though he did not cite Bergson," Ash notes, Wertheimer's tachistoscope studies had, at least by the time of their full articulation around 1920, "provided empirical evidence for the claims the Frenchman had made" (Ash 1995, 9-10, 69, 128-129). Such influence was nevertheless double-edged as far as Bergson's cinematographic epistemology was concerned. In deploying cinematographs as experimental (rather than conceptual) devices, psychologists were beginning to arrive at an appreciation of them as holding a quite different significance to that ascribed by Bergson.

The most significant study to emerge from early twentieth-century experimental psychology as far as the conceptualization of the cinematograph as we understand it today was concerned however was that of Münsterberg. As well as becoming the most significant institutional rival to James at Harvard, Münsterberg embarked on a lengthy series of studies that sought to gauge the psychological significance of cinema as an experiential medium (Blatter 2015; Brain 2012; Bruno, 2009. On Münsterberg and James's rivalry see Bordogna 2008, 224-255). Significantly, Münsterberg's principal publication on the topic not only adopted a conception of the relation between stimulation and sensation that drew directly on the experimental tradition to which Sherrington sought to contribute, but characterized the cinematograph itself in radically different terms to those Bergson had employed. The Photoplay ${ }^{28}$ (1916) conveyed a conception of cinematographs not as exemplifying a particular mode of apprehension, but as a means by which specific conceptions of natural and human existence found expression. For Münsterberg, the representational possibilities of cinematography did not reduce phenomena to analytic moments, but rather brought the motile aspects of even things hitherto considered "lifeless" to the attention of interested observers. In the photoplay, "our ideas and feelings and impulses group themselves around the attended object. It becomes the starting point for our actions while all the other objects in the sphere of our senses lose their grip on our ideas and feelings" (Münsterberg 1916, 85). Bergson's claims regarding the active shaping of life by mind are for Münsterberg only made possible by the photoplay, wherein "it is as if reality ... has become shaped by the demands of our soul." Indeed, it is as if, through the cinematograph, "the outer world were woven into our mind and were shaped ... by the acts of our attention" (Münsterberg 1916, 91, 95). It is not for Münsterberg in the vital body, but in the production of cinematic effects that the active aspects of consciousness find their expression. Such productions are moreover irretrievably both simultaneously technical and performative. Where Bergson's cinematograph was entirely "automatic," Münsterberg found the most interesting effects of cinematography

\footnotetext{
${ }^{28}$ https://cslide.medsci.ox.ac.uk/items/view/8714 (last accessed September 11, 2017).
} 
to depend on its operators: "the same series of moving pictures may be given to us with a very slow or with a rapid turning of the crank," and thus produce very different emotive and perceptual effects (Münsterberg 1916, 127-128). The Photoplay thereby marks the cinematographic culmination of a specifically technical tradition of psychological research, in which cinematographs feature not as devices whose workings reveal the nature of mental existence, or even as counterpoints to a philosophically promising mode of investigation, but as a means of extending mind into the world (Brain 2012, esp. 330-334, 341-349). In stark contrast to Bergson's "intuitive" vital mind, Münsterberg thereby posited cinematographs as the then-pre-eminent means of psychological (and by implication vital) realization.

By the end of the First World War then, a number of strands of experimental physiological and psychological research had emerged that both avoided the cinematographic characterization that Bergson had put forward in 1907, and asserted a radically different set of claims concerning life, perception, and the technical conditions of experience than Bergson had proposed. Firstly, regarding the nature of nervous life, the formulation of a physical rather than a mechanical or a vitalist physiology enabled physiologists to incorporate vitalist claims within explanatory schema that continued to address living matter as subject to natural law more generally. Secondly, the emergence of kymograph-centered approaches to the bodily manifestation of emotion contributed to a more general differentiation between physiological and psychological endeavor. This differentiation encouraged physiologists to cordon off studies of visceral emotional effects from the consideration of emotions per se a topic that was increasingly left to specialists in psychological fields. And finally, an increasing emphasis on studies of visual illusion within physiological psychology led to ever more sophisticated forms of experimentation with cinematographic devices and tools relating to them. Within Sherrington's physical physiology, this experimentation constituted a limit case that demonstrated the inability of studies of sensory experience to speak to questions concerning the nature of bodily processes. Experimental psychologists such as Münsterberg, on the other hand, began to articulate a conception of cinematography that constituted a definite alternative to Bergson's idealization. Bergson's cinematograph had by 1920 thus become more a caricature rather than (as it had been in 1907) a fair characterization of predominant modes of conduct within these sciences. Moreover, these very sciences had accommodated the alternative conception of existence to which he subscribed within separate disciplinary realms.

The trends enumerated above did not go uncontested. For those most enthused by Bergson's ideas the relevance of metaphysical and (especially) psychological speculation to the study of life remained self-evident; an assumption confirmed in Bergson's insistence during his debate with Einstein that physical nature could not be treated as independent of the embodied experience of duration. In addition to the philosophers and physicists addressed by Canales, Sherrington, along with Cannon, Münsterberg, Wertheimer, and others, continued to contribute to a wider effort to discredit such 
assertions. In May 1918, for example, Sherrington played a critical role in preventing one of the most prominent figures in Germany sympathetic to Bergson's philosophy from gaining a hearing in post-First World War Britain. As Mark Chapman recounts, Sherrington adopted a seemingly highly contradictory attitude towards intellectual rapprochement at the end of the war. On the one hand, he presided over the election of Einstein as a Foreign Member of the Royal Society, thereby contributing to the acknowledgment that German physics had attained something approaching international ascendancy over the previous decades. Yet it was also almost entirely down to Sherrington that the German theologian Ernst Troeltsch, himself hailed as "a kind of Einstein of the religious world," failed to gain a hearing in the country (Chapman 2017, 106-122; Chapman 2001, 180). At a crucial moment, just as negotiations for Troeltsch to tour Britain were being finalized, Sherrington wrote to The Times alleging that the theologian (with whom he claimed he had briefly been acquainted) had in conversation with him in 1907 expressed deeply belligerent views on Germany's superiority over Britain as a nation. Sherrington's “inexplicable intervention" (Chapman 2017, 118) is only comprehensible if the context of the broader debate regarding the relation between science and intuition, and the relevance of perception studies to philosophical speculation, is taken into account. Troeltsch had over the previous three decades articulated a set of theological and historical claims which, in their assertion of the "irrational" primacy of the creative act and the necessity of this act to comprehension of individual action, had deep resonances with those of Bergson (Ricci 2012, chap. 4, esp. 72-73). Less abstractly, during the war Troeltsch had accused the neo-Kantian journal Kant-Studien, of which Einstein's supporter Ernst Cassirer was an editor, of having descended into "Jewish terrorism" (Gordon 2010, 56; Canales 2015, 132-135; on Cassirer's relation to psychophysics, see Biagioli 2016; Giovanelli 2017, esp. 287-288, 313-316). Ash has noted the extent to which both experimental psychologists and physical realists found themselves under attack from philosophers and theologians in inter-war Germany (Ash 1995, 286, 288-291). In supporting Einstein and undermining Troelstch, Sherrington thus may well have considered himself to be participating in a broader defense of the disciplinary interests of physical physiology and experimental psychology, both in Britain and further afield.

In his 1922 reference to psychological time as the only alternative to his own physical time, Einstein appealed not then to a field in which contentions regarding the nature of mind could directly inform studies of the nature of bodies, but rather to an increasingly laboratory-based discipline that addressed questions that at least nominally fell outside of the purview of physiological research. It is significant in this respect that he had since 1916 cultivated a close relationship with Wertheimer. In 1922 Einstein asked Wertheimer to deputize for him at the League of Nations' Committee on Intellectual Cooperation, over which Bergson presided, and under the auspices of which the two debated. In the same year, in the first of a number of such letters, he also penned a recommendation for him (to Moritz Schlick at Kiel) on the basis of both his personal 
acquaintance and his psychological expertise. ${ }^{29}$ Though Einstein was eventually persuaded by Wertheimer that he would be the most appropriate representative of Germany on the Committee (thus precipitating the debate), it is notable that it was the experimental psychologist (and founder of the Institut de Psychologie) Piéron that spoke most incisively for Einstein's point of view there. Indeed, that Piéron appealed precisely to experiments in which "two symmetrical points of the retina receive a luminous impression" (a direct reference to Sherrington's cinematograph studies) to insist that Bergson's introspective duration must remain "a foreigner to physical time" at the Paris debate indicates the critical role that experimentation with cinematographic devices played in constituting a psychology that could accommodate Bergson's claims (Anon. 1922, 369-370). ${ }^{30}$ In psychological experimentation with illusion-generating equipment, Bergson's "cinematographic" admonition that experience could not be reduced to a set of isolated moments had, paradoxically, found purchase in the very ground that he sought to critique. Laboratory psychology incorporated his insistence on the holistic, intuition-centered, active nature of perception, but produced it as a scientific object rather than philosophic insight. Indeed, cinematographic devices came to be positioned by figures such as Münsterberg as material corollaries of this object. Crucially, such adoption by psychologists of concepts emphasized by Bergson did not rely on more general claims regarding the place of mind in life, but rather on the claim that they could speak to specific propositions regarding the nature of sensory or affective experience. Problematically for Bergson, it had been exactly this particularization of discussion that his philosophy sought to ward against: for him, direct, unmediated experience should be the grounds for the apprehension of nature as a whole, rather than specific psychological, physiological, or indeed physical parts of it.

\section{Conclusion}

Given the above changing conditions in relation to which Bergson articulated his philosophy, his dispute with Einstein begins to appear in a different light. Canales relays a Bergson under attack, subject to the imperialistic impulses of a radical, ambitious and somewhat ruthless early twentieth-century physics (Canales 2015, esp. 13, 163-171). In contrast, this article has conveyed a Bergson deeply invested in a historically specific mode of intellectual practice in which consideration relating to sensation had direct relevance to that relating to bodily nature. Einstein's dispute with Bergson came at a

\footnotetext{
${ }^{29}$ M. Wertheimer to A. Einstein, 17th Sept. 1922 and A. Einstein-M. Schlick, 28th Apr. 1922, trans. in Luchins and Luchins 1979, 173-174 and 181. Einstein and Bergson's League of Nations experiences (though not Einstein's invitation to Wertheimer) are related in Canales 2015, esp. 114-130.

30 “supposons que deux points symétriques de la rétine reçoivent une impression lumineuse; il semble que, dans ces conditions, la simultanéité perçue sera un indice certain, dans les limites d'une approximation donnée, de simultanéité physique... la durée bergsonienne me paraît devoir rester étrangère au temps physique en général et particulièrement au temps einsteinien."
} 
time in which this mode was undergoing severe and seemingly irreversible decline. Einstein and his followers' success in casting Bergson's philosophy as outside of the purview of a properly scientific culture had as much to do with the disintegration of this mode as with the specificities of their encounter. The constitution of a psychological science that did not necessarily refer directly to physiology (and vice versa) was a critical condition for Bergson's characterization as scientifically inappropriate. That Bergson did not appeal to psychological or physiological science in 1922, then, reflected the changing structure of academic endeavor during the previous two decades.

This is not however to dismiss the significance of either Bergson's claims regarding the primacy of intuitive experience in philosophical investigation, or Canales' conclusions regarding the cultural positioning of Bergson during the twentieth century. Indeed, the two insights are linked in significant ways. Though it remained outside the purview of the experimental disciplines, Bergson's introspection-derived insistence on the inherent temporality of experience became a critical source of both insight and provocation for science-oriented philosophy. Though the thinkers who are most frequently identified with his thought are Alfred North Whitehead, Georges Canguilhem, and Gilles Deleuze, recent work has demonstrated the importance of Bergsonian themes in structuring work by Jean Cavaillès, Maurice Merleau-Ponty, Michel Foucault, and others (Bianco 2011; further explicated in Bianco 2015). In the United States, Arthur O. Lovejoy drew on Bergson's writings for his explorations of "organic autonomy" and the history of evolutionary concepts (Russell 2015, esp. 4346 and 62-63). Canales' concerns mesh well with a body of work which, as Ruth Leys notes, has become especially prominent in conjunction with appeals to biology as a transhistorical mode of explanation (Leys 2011, 441-443). Nevertheless, as this paper suggests, a significant problem with the rehabilitation of Bergson's philosophy specifically is that his holistic epistemology has not been able to accommodate the establishment of experimentation as a critical guarantor of intellectual legitimacy in fields in which his followers participate. During the first part of the twentieth century, particular experimental fields brought particular aspects of Bergson's claims to bear on their objects of study. Thus holistic functional explanation came to complement rather than supplant particular structural delineation in physiology. Intuitive perceptual experience was similarly brought into contact with but did not supersede the analysis and recording of sensory experience and response in psychology. In each case, strong "Bergsonian" claims regarding the primacy of intuitive perception were not refuted but rather moderated and incorporated into already-existing traditions via disciplined interaction with technical entities.

The insight of Bergson's most relevant to present-day historical practice then is not that relating to the primacy of intuition in psychological experience, or an organic vital force, or even a temporal absolute, but rather his insistence that all intellectual endeavor simultaneously responds to and constitutes material change (i.e. occurs within history). With Bergson, we cannot expect either the current contentions of psychology, 
biology, or physics, or the plausibility of particular ethical, aesthetic, or indeed historical interpretations to remain absolutely stable. Most importantly, we certainly cannot expect the currently accepted means by which knowledge in any of these fields (or their progeny) is established to persist indefinitely. Bergson's philosophy speaks to current modes of historical investigation - not least in its assertion that all experience (including that on which the claims of both physical science and philosophy are based) is in some sense that of a past (Bergson [1896] 1988, 71-76; Kerslake 2008; Amad 2010, esp. 117-123 and 166-170; Lundy 2013). Yet his attempt to locate the material presence of philosophic insight primarily within the living body foundered in the face of the establishment of experimental disciplinary practices. One way of addressing Bergson historiographically then might be, as this paper has attempted, to consider his thought in relation not only to contemporary ideals of bodily and psychological nature, or even to historically and geographically specific modes of embodied experience, but also, simultaneously, to the technical (and with them institutional) changes ${ }^{31}$ that accompany their respective performance and articulation. Historians, like physiologists and psychologists before them, might thereby come to a more acute appreciation of technical entities not only as objects of historical explanation, but also as contingent, contested, and potentially deeply problematic constituents of the disciplinary study of history itself.

\section{Acknowledgments}

I am grateful for the careful attention of the two anonymous referees, which improved the text immeasurably. My interest in historical relations between philosophy and physiology was prompted by my thesis supervisor, Stephen Jacyna, and revived by the 'CSlide' project developed at DPAG (Oxford) by Zoltan Molnar, Pietro Corsi, and Damion Young. As the principal programmer for CSlide, Jon Mason created the means by which I both conducted and now convey my research. Further invaluable advice and inspiration came from Rachel Bower, Åsa Jannson, Fabio de Sio, and Chris Millard. The research was supported by the Wellcome Trust via the CSlide project and a University of Leeds ISSF Research Fellowship (Grant Numbers 097123 and 108503 respectively).

\section{Archives}

Sherrington Collection. c.1894-1952. Sherrington Library. Department of Physiology, Anatomy and Genetics. University of Oxford.

Sir Charles Scott Sherrington Fonds. 1663-1976. RBSC-ARC-1733. University of British Columbia Library Rare Books and Special Collections. University of British Columbia, Vancouver.

\footnotetext{
${ }^{31}$ https://cslide.medsci.ox.ac.uk/ (last accessed September 11, 2017).
} 


\section{References}

Amad, Paula. 2010. Counter-Archive: Film, The Everyday, and Albert Kahn's Archives de la Planète. New York: Colombia University Press.

Anon. 1922. "La Théorie de la relativité: séance du 6 avril 1922." Bulletin de la Société française de philosophie 22:91-113.

Antliff, Mark. 1993. Inventing Bergson: Cultural Politics and the Parisian Avant-Garde. Princeton: University Press.

Araujo, Saulo de Freitas. 2016. Wundt and the Philosophical Foundations of Psychology. New York: Springer.

Ash, Mitchell G. 1995. Gestalt Psychology in German Culture, 1890-1967: Holism and the Quest for Objectivity. Cambridge: University Press.

Banks, Erik C. 2001. "Ernst Mach and the Episode of the Monocular Depth Sensations." Journal of the History of the Behavioral Sciences 37:237-348.

Barkan, Diana Kormos. 1999. Walter Nernst and the Transition to Modern Physical Science. Cambridge: University Press.

Benschop, Ruth. 1998. "What is a Tachistoscope? Historical Explorations of an Instrument." Science in Context 11:23-50.

Bergson, Henri-Louis. [1889] 1910. Time and Free Will: An Essay on the Data of Consciousness. Translated by F. L. Pogson. London: George Allen and Unwin.

Bergson, Henri-Louis. [1896] 1988. Matter and Memory. Translated by Nancy M. Paul and W. Scott Palmer. New York: Zone Books.

Bergson, Henri-Louis. [1907] 1911. Creative Evolution. Translated by Arthur Mitchell, . New York: Henry Holt and Co.

Bergson, Henri-Louis. [1922] 1999. Duration and Simultaneity: Bergson and the Einsteinian Universe. Translated by Leon Jacobson. Manchester: Clinamen Press.

Bergson, Henri-Louis. [1934] 1946. "The Perception of Change." In The Creative Mind: An Introduction to Metaphysics, translated by Mabelle L. Andison, 153-186. New York: The Philosophical Library.

Bianco, Guiseppe. 2011. "Experience v's Concept? The Role of Bergson in Twentieth-Century French Philosophy." The European Legacy 16:855-872.

Bianco, Guiseppe. 2015. Après Bergson: Portrait de group avec philosophe. Paris: Presses Universitaires de France.

Biagioli, Francesca. 2016. Space, Number, and Geometry from Helmholtz to Cassirer. New York: Springer.

Black, Sandra Elizabeth. 1981. ““The Osler Medal Essay”: Pseudopods and Synapses: The Amoeboid Theories of Neuronal Mobility and the Early Formation of the Synapse Concept." Bulletin of the History of Medicine 55:34-58.

Blatter, Jeremy. 2015. "Screening the Psychological Laboratory: Hugo Münsterberg, Psychotechnics, and the Cinema, 1892-1916." Science in Context 28:53-76.

Bloch, Adolph-Moïse. 1885. "Expériences sur la vision." Comptes rendus des séances de la Société de biologie 37:493-495.

Bordogna, Francesca. 2008. William James at the Boundaries: Philosophy, Science, and the Geography of Knowledge. Chicago and London: University of Chicago Press.

Brain, Robert Michael. 2009. "Protoplasmania." In The Art of Evolution: Darwin, Darwinisms, and Visual Culture, edited by Barbara Larson and Fae Brauer, 92-123. Hanover NH: Dartmouth College Press.

Brain, Robert Michael. 2012. "Self-Projection:Hugo Münsterberg on Empathy and Oscillation in Cinema Spectatorship." Science in Context 25:329-353.

Brain, Robert Michael. 2013. "Materialising the Medium: Ectoplasm and the Quest for Supra-Normal Biology in Fin-de-Siècle Science and Art." In Vibratory Modernism, edited by Anthony Enns and Shelley Trower, 115-144. Basingstoke: Palgrave Macmillan.

Brain, Robert Michael. 2015. The Pulse of Modernism: Physiological Aesthetics in fin-de-siècle Europe. Seattle and London: University of Washington Press. 
Brain, Robert Michael and Wise, Matthew Norton. 1994. "Muscles and Engines: Indicator Diagrams and Helmholtz's Graphical Methods.” In Universalgenie Helmholtz: Rückblick nach 100 Jahren, edited by Lorenz Krüger, 124-148. Berlin: Akademie Verlag.

Bruno, Guiliana. 2009. "Film, Aesthetics, Science: Hugo Münsterberg's Laboratory of Moving Images." Grey Room 36:88-113.

Breidbach, Olaf. 1996. "The Controversy over Stain Technologies: An Experimental Reexamination of the Dispute on the Cellular Nature of the Nervous System around 1900." History and Philosophy of the Life Sciences 18:195-212.

Bull, Lucien. 1910. “La chronophotographie des mouvement rapides," Travaux de l'association l'Institut Marey 2:51-75.

Canales, Jimena. 2009. A Tenth of a Second: A History. Chicago and London: Chicago University Press.

Canales, Jimena. 2011. "Desired Machines: Cinema and the Word in its Own Image." Science in Context 24:329-359.

Canales, Jimena. 2015. The Physicist and the Philosopher: Einstein, Bergson, and the Debate That Changed Our Understanding of Time. Princeton and Oxford: Princeton University Press.

Cannon, Walter B. 1915. Bodily Changes in Pain, Hunger, Fear and Rage: An Account of Recent Researches into the Function of Emotional Excitement. New York and London: D. Appleton and Company.

Carroy, Jacqueline, and Henning Schmidgen. 2002. "Psychologies Experimentales: Leipzig-Paris (18901910)." Max-Planck-Institut für Wissenschaftsgeschichte Preprint 206. Berlin Max-Planck-Institut für Wissenschaftsgeschichte.

Cartwright, Lisa. 1995. Screening the Body: Tracing Medicine's Visual Culture. Minneapolis and London: University of Minnesota Press.

Cat, Jordi. 2013. Maxwell, Sutton and the Birth of Colour Photography. Basingstoke: Palgrave Macmillan.

de Chadarevian, Soraya. 1993. "Graphical Method and Discipline: Self-Recording Instruments in Nineteenth-Century Physiology." Studies in History and Philosophy of Science Part A 24: 267-291.

Chapman, Mark D. 2001. Ernst Troeltsch and Liberal Theology: Religion and Cultural Synthesis in Wilhelmine Germany. Oxford: University Press.

Chapman, Mark D. 2017. Theology at War and Peace: English Theology and Germany in the First World War. Abingdon: Routledge.

Charpentier, Augustin. 1890. "Recherches sur la persistence des impressions rétiniennes et sur les excitations lumineuses de courte durée." Archives d'Opthalmologie 10: 10, 108-135, 212-230, 340-356, 406-429, and 522-537.

Clarke, Edwin, and L. Stephen Jacyna. 1987. Nineteenth-Century Origins of Neuroscientific Concepts. Berkeley and Los Angeles CA and London: University of California Press.

Crary, Jonathan. 1999. Suspensions of Perception: Attention, Spectacle, and Modern Culture. Cambridge: MIT Press.

CSlide, Ver. 1.0. 2014. Department of Physiology, Anatomy and Genetics, University of Oxford. 4 January 2017. https://cslide.medsci.ox.ac.uk/.

Daston, Lorraine. 1978. "British Responses to Psycho-Physiology, 1860-1900.” Isis 69:192-208.

Daston, Lorraine, and Peter Galison. 2007. Objectivity. New York: Zone Books.

De Palma, Armando, and Germana Pareti. 2011. "Bernstein's Long Path to Membrane Theory: Radical Change and Conservation in Nineteenth-Century Electrophysiology." Journal of the History of the Neuroscoiences 20:306-337.

Deigh, John. 2014. "William James and the Scientific Study of Emotion." Emotion Review 6:4-12.

Dercum, Francis Xavier. 1896. "The Functions of the Neuron." Journal of Nervous and Mental Diseases 23:513-523.

Dixon, Thomas. 2003. From Passions to Emotions: The Creation of a Secular Psychological Category. Cambridge: University Press. 
Douglass, Paul. 1999. “Bergson and Cinema: Friends or Foes?” In The New Bergson, edited by John Mullarky, 209-227. Manchester: University Press.

Dror, Otneil E. 1999a. "The Affect of Experiment: The Turn to Emotions in Anglo-American Physiology, 1900-1940.” Isis 90:205-237.

Dror, Otniel E. 1999b. "The Scientific Image of Emotion: Experience and Technologies of Inscription.” Configurations 7:355-401.

Dror, Otniel E. 2006. "Fear and Loathing in the Laboratory and Clinic." In Medicine, Emotion, and Disease, 1700-1950, edited by Fay Bound Alberti, 125-143. Basingstoke: Palgrave Macmillan.

Dror, Otniel E. 2011. "Seeing the Blush: Feeling Emotions." In Histories of Scientific Observation, edited by Lorraine Daston and Elizabeth Lunbeck, 326-348. Chicago: Universtiy Press.

Dror, Otniel E. 2014. "The Cannon-Bard Thalmic Theory of Emotions: A Brief Genealogy and Reappraisal.” Emotion Review 6:13-20.

During, Elie 2015. "Notes on the Bergsonian Cinematograph.” Translated by Franck le Gac. In CineDispositives: Essays in Epistemology across Media, edited by François Albera and Maria Tortajada, 115-128. Amsterdam: University Press.

Engstrom, Eric J. 2003. Clinical Psychiatry in Imperial Germany: A History of Psychiatric Practice. Ithaca NY: Cornell University Press.

Fearing, Franklin. [1930] 1970. Reflex Action: A Study in the History of Physiological Pscyhology. Cambridge and London: MIT Press.

Finkelstein, Gabriel. 2013. Emil du Bois-Reymond: Neuroscience, Self, and Society in Nineteenth-Century Germany. Cambridge and London: MIT Press.

Fitzgerald Des, and Felicity Callard. 2015. "Social Science and Neuroscience beyond Interdisciplinarity: Experimental Entanglements." Theory, Culture \& Society 32:3-32.

Friedman, Michael, and Alfred Nordmann, eds. 2006. The Kantian Legacy in Nineteenth-Century Science. Cambridge and London: MIT Press.

Garson, Justin. 2015. "The Birth of Information in the Brain: Edgar Adrian and the Vacuum Tube." Science in Context 28:31-52.

Geison, Gerald L. 1978. Michael Foster and the Cambridge School of Physiology: The Scientific Enterprise in Late Victorian Society. Princeton: University Press.

Giovanelli, Marco. "The Sensation and the Stimulus: Psychophysics and the Prehistory of the Marburg School." Perspectives on Science 25:287-323.

van Gieson, Ira. 1899. The Correlation of Sciences in the Investigation of Nervous and Mental Disease. Utica NY: State Hospitals Press.

Gilles, Mary Ann. 1996. Henri Bergson and British Modernism. Montreal: McGill-Queen's University Press.

Gordon, Peter E. 2010. Continental Divide: Heidegger, Cassirer, Davos. Cambridge and London: Harvard University Press.

Green, Christopher D. 2010. "Scientific Objectivity and E. B. Titchener's Experimental Psychology." Isis 101:697-721.

Grogin, Robert C. 1988. The Bergsonian Controversy in France, 1900-1914. Calgary: University Press.

Grünbaum, Otto Fritz Frankeau. 1897- 1898. “On Intermittent Stimulation of the Retina.” Parts I and II, Journal of Physiology 21:396-402 and 22:433-450.

Gunning, Tom. [1986] 2006. "The Cinema of Attraction[s]: Early Film, The Spectator, and the Avant Garde." In The Cinema of Attractions Reloaded, edited by Wanda Strauven, 381-388. Amsterdam: University Press.

Hatfield, Gary. 1990. The Natural and the Normative: Theories of Spatial Perception from Kant to Helmholtz. Cambridge and London: MIT Press.

Hayward, Rhodri. 2007. Resisting History: Religious Transcendence and the Invention of the Unconscious. Manchester: University Press.

Heidelberger, Michael. [1993] 2004. Nature from Within: Gustav Theodor Fechner and His Psychophysical Worldview. Translated by Cynthia Klohr. Pittsburgh PA: University Press. 
Hering, Ewald. 1900. “On the Theory of Nerve Activity.” The Monist 10:167-187.

Jacyna, L. Stephen. 1981. "The Physiology of Mind, the Unity of Nature, and the Moral Order in Victorian Thought." British Journal for the History of Science 14:109-132.

James, William. 1884. "What is an Emotion?" Mind 9:188-205.

James, William. 1894. “The Physical Basis of Emotion.” Psychological Review 1:516-529.

Kerslake, Christian. 2008. "Becoming Against History: Toynbee, Deleuze, and Vitalist Historiography." Parrhesia 4:17-48.

Landecker, Hannah. 2006. "Microcinematography and the History of Science and Film." Isis 97:121-132.

Landecker, Hannah. 2011. "Creeping, Drinking, Dying: The Cinematic Portal and the Microscopic World of the Twentieth-Century Cell." Science in Context 24:381-416.

Latour, Bruno. 2005. "Trains of Thought: The Fifth Dimension and its Fabrication.” In Thinking Time: A Multidisciplinary Perspective on Time, edited by Anne-Nelly Perret-Clermont, et. al., 173-187. Cambridge MA: Hogrefe and Hupher.

Lawrence, Christopher. 2009. "Degeneration under the Microscope at the fin de siècle." Annals of Science 66:455-471.

Leary, David E. 1982. "Immanuel Kant and the Development of Modern Psychology." In The Problematic Science: Psychology in Nineteenth-Century Thought, edited by William Ray Woodward and Mitchell G. Ash, 17-42. New York: Praeger.

Lefebvre, Alexandre, and Melanie White, eds. 2012. Bergson, Politics and Religion. Durham NC and London: Duke University Press.

Lenoir, Timothy. 1986. "Models and Instruments in the Development of Electrophysiology." Historical Studies in the Physical and Biological Sciences 17:1-54.

Lenoir, Timothy. 1987. "Social Interests and the Organic Physics of 1847." In Science in Reflection. The Israel Colloquium: Studies in History, Philosophy, and Sociology of Science 3, edited by Edna Ullmann-Margalit, 169-191. Dordrecht, Boston, and London: Kluwer.

Lenoir, Timothy. 1993. “"The Eye as Mathematician: Clinical Practices, Instrumentation, and Helmholtz's Construction of an Empiricist Theory of Vision." In Hermann von Helmholtz and the Foundations of Nineteenth-Century Science, edited by David Cahan, 109-153. Berkeley and London: University of California Press.

Lesch, John E. 1984. Science and Medicine in France: The Emergence of Experimental Physiology, 1790-1855. Cambridge MA, and London: Harvard University Press.

Leys, Ruth. 2011. "The Turn to Affect: A Critique." Critical Inquiry 37:434-472.

Loerzer, Barbara. 2014. "William James, the French Tradition, and the Incomplete Transposition of the Spiritual into the Aesthetic." In William James and the Transatlantic Conversation: Pragmatism, Pluralism, and the Philosophy of Religion, edited by Martin Halliwell and Joel D. S. Rasmussen, 65-80. Oxford: Oxford University Press.

Luchins, Edith H. and Abraham S. Luchins. 1979. "Introduction to the Einstein-Wertheimer Correspondence." Methodology and Science 12:165-202.

Lundy, Craig. 2013. "Bergson, History and Ontology." In Bergson and the Art of Immanence: Painting, Photography, Film, Performance, edited by John Mullarky and Charlotte de Mille, 17-31. Edinburgh: University Press.

McDougall, William. 1898. “A Contribution towards Improvement in Psychological Method.” Parts I and III, Mind (New Series) 7:15-33, and Mind (New Series) 7:364-387.

McDougall, William. 1901a. "Some New Observations in Support of Thomas Young's Theory of Lightand Colour-Vision." Parts I and II, Mind (New Series) 10:52-97 and Mind (New Series) 10:210-245.

McDougall, William. 1901b. "On the Seat of the Psycho-Physical Processes." Brain 24:579-630.

McDougall, William. 1903. "The Nature of Inhibitory Processes within the Nervous System." Brain 26:153-191.

McDougall, William. 1908. An Introduction to Social Psychology. London: Methuen \& Co.

McDougall, William. 1911. Body and Mind: A History and Defence of Animism. New York: Macmillan. 
McDougall, William. 1961. "William McDougall.” In A History of Psychology in Autobiography, vol. I, edited by Carl Murchison, 191-223. New York: Russell and Russell.

McGrath, Larry. 2015. "Confronting the Brain in the Classroom: Lycée Policy and Pedagogy in France, 1874-1902." History of the Human Sciences 28:3-24.

Macdonald, John Smyth. 1900. "The Demarcation Current of Mammalian Nerve. (Preliminary Communication), II: The Source of the Demarcation Current Considered as a Concentration Cell." Proceedings of the Royal Society 67:315-324.

Mannoni, Laurent. [1994] 2000. The Great Art of Light and Shadow: Archaeology of the Cinema. Translated by Richard Crangle. Exeter University Press.

Marbe, Karl. 1898. “Die stroboskopischen Erscheinungen.” Philosophische Studien 14:376-401.

Massey, Heath. 2014. "Bergsonian Intuition: Getting Back into Duration.” In Rational Intuition: Philosophical Roots, Scientific Investigations, edited by Lisa M. Osbeck and Barbara S. Held, 151-173. New York: Cambridge University Press.

Moruno, Dolores Martin. 2016. "Pain as Practice in Paolo Mantegazza's Science of Emotions." Osiris 31:137-162.

Mullarky, John, ed. 1999. The New Bergson. Manchester and New York: Manchester University Press.

Mullarky, John, and Charlotte de Mille, eds. 2013. Bergson and the Art of Immanence: Painting, Photography, Film, Performance. Edinburgh: University Press.

Mussell, James. 2009. "Private Practices and Public Knowledge: Science, Professionalization and Gender in the Late Nineteenth Century." Nineteenth-Century Gender Studies 5(2) November 2016 http://www. ncgsjournal.com/issue 52/mussell.htm.

Münsterberg, Hugo. 1916. The Photoplay: A Psychological Study. New York and London: D. Appleton.

Nawrotski, Kristen, and Jack Dougherty, eds. 2013. Writing History in the Digital Age. Ann Arbor: University of Michigan Press.

Normandin, Sebastian, and Charles T. Wolfe, eds. 2013. Vitalism and the Scientific Image in Post-Enlightenment Life Science, 1800-2010. Dordrecht: Springer.

O'Connor, Walter J. 1991. British Physiologists 1885-1914: A Biographical Dictionary. Manchester: University Press.

Oldfield, Richard. Charles, . 1950. "Psychology in Oxford - 1898-1949." Part II, Quarterly Bulletin of the British Psychological Society 1:382-387.

Otis, Laura. 2001. Networking: Communicating with Bodies and Machines in the Nineteenth Century. Ann Arbor: University of Michigan Press.

Pickstone, John V. 2000. Ways of Knowing: A New History of Science, Technology and Medicine. Manchester: University Press.

Ramalingam, Chitra. 2013. "The Most Transitory of Things: Talbot and the Science of Instantaneous Vision.” In William Henry Fox Talbot: Beyond Photography, edited by Mirjam Brusius, Katrina Dean, and Chitra Ramalingam, 245-268. New Haven: Yale University Press.

Ramalingam, Chitra. 2015. "Dust Plate, Retina, Photograph: Imaging on Experimental Surfaces in Early Nineteenth-Century Physics." Science in Context 28:317-355.

Rees, Danny. 2014. "Down in the Mouth: Faces of Pain." In Pain and Emotion in Modern History, edited by Robert Gregory Boddice, 164-186. Basingstoke: Palgrave Macmillan.

Rheinberger, Hans-Jörg. 1997. Toward a History of Epistemic Things: Synthesizing Proteins in the Test Tube. Stanford: University Press.

Ricci, Gabriel R. 2012. The Tempo of Modernity. New Brunswick NJ: Transaction.

Rood, Ogden N. 1893. "On a Photometric Method which is Independent of Color." American Journal of Science 46:173-176.

Russell, Douglas. 2015. “Toward a Pragmatist Epistemology: Arthur O. Lovejoy's and H. S. Jenning's Biophilosophical Responses to Neovitalism." Journal of the History of Biology 48:37-66.

Schäfer, Edward A. 1900. "'The Nerve Cell." In Textbook of Physiology, edited by Edward A. Schäfer, 592615. London and Edinburgh: Young J. Pentland. 
Schaffer, Simon. 2004. "A Science Whose Business is Bursting: Soap Bubbles as Commodities in Classical Physics." In Things that Talk: Object Lessons from Art and Science, edited by Lorraine Daston, 147-192. New York: Zone Books.

Schenck, Freidrich Wilhelm Julius. 1896. "Ueber intermittirende Netzhautreizung." Pflüger's Archiv für die gesamte Physiologie des Menschen und der Tiere 64:165-178.

Schickore, Jutta. 2006. "Misperception, Illusion and Epistemological Optimism: Vision Studies in Early Nineteenth-Century Britain and Germany." British Journal for the History of Science 39:383405.

Schloegel, Judy Johns, and Henning Schmidgen. 2002. "General Physiology, Experimental Psychology, and Evolutionism: Unicellular Organisms as Objects of Psychophysiological Research, 1877-1918." Isis 93:614-645.

Schmidgen, Henning. 2008. 'Münsterberg's Photoplays: Instruments and Models in his Laboratories at Freiburg and Harvard (1891-1893)', at The Virtual Laboratory, Max Planck Institut für Wissenschaftsgeschichte. http://vlp.mpiwg-berlin.mpg.de/essays/data/art71? $\mathrm{p}=1$ (last accessed November 18, 2016).

Schmidgen, Henning. 2012. "Cinematography Without Film: Architectures and Technologies of Visual Instruction in Biology around 1900.” In The Educated Eye: Visual Culture and Pedagogy in the Life Sciences, edited by Nancy Anderson and Michael R. Dietrich, 94-120. Hanover: Dartmouth College Press.

Schmidgen, Henning. [2009] 2014. The Helmholtz Curves: Tracing Lost Time. Translated by Nils F. Schott. New York: Fordham University Press.

Seyfarth, Ernst-August. 2006. "Julius Bernstein (1839-1917): Pioneer Neurologist and Biophysicist." Biological Cybernetics 94:2-8.

Sherrington, Charles Scott. 1893. "Note on the Spinal Portion of Some Ascending Degenerations." Journal of Physiology 14:255-302.

Sherrington, Charles Scott. 1894. "On the Anatomical Constitution of Nerves of Skeletal Muscles; with Remarks on Recurrent Fibres in the Ventral Spinal Nerve-Root." Journal of Physiology 17: 210-254.

Sherrington, Charles Scott. 1899- 1900. "Experiments on the Vascular and Visceral Factors for the Genesis of Emotion." Proceedings of the Royal Society of London 66:390-403.

Sherrington, Charles Scott. 1900. "Experimentation on Emotion.” Nature 62:328-331.

Sherrington, Charles Scott. 1904. "On Binocular Flicker and the Correlation of Activity of 'Corresponding' Retinal Points." Journal of Psychology 1:26-60.

Sherrington, Charles Scott. [1906] 1947. The Integrative Action of the Nervous System. Cambridge: University Press.

Sherrington, Charles Scott. 1921. "Break-Shock Reflexes and 'Supramaximal' Contraction-Response of Mammalian Nerve-Muscle to Single Shock Stimuli." Proceedings of the Royal Society of London B 92:245258.

Sidis, Boris. 1919. The Psychology of Suggestion: A Research into the Subconscious Nature of Man and Society. New York: D. Appleton.

Smith, Roger. 1973. "The Background of Physiological Psychology in Natural Philosophy." History of Science 11:75-123.

Smith, Roger. 1992. Inhibition: History and Meaning in the Sciences of Mind and Brain.London: Free Association Books.

Smith, Roger. 2000. “The Embodiment of Value: C.S. Sherrington and the Cultivation of Science.” British Journal for the History of Science 33:283-311.

Smith, Roger. 2001a. "Physiology and Psychology, or Brain and Mind, in the Age of Sherrington." In Psychology in Britain: Historical Essays and Personal Reflections, edited by Geoff, C. Bunn Lovie, A. D., and Graham D. Richards, 223-242. Leicester: BPS Books.

Smith, Roger. 2001b. "Representations of Mind: C.S. Sherrington and Scientific Opinion, c.1930-1950." Science in Context 14:511-539. 
Smith, Roger. 2003. "Biology and Values in Interwar Britain: C.S. Sherrington, Julian Huxley, and the Vision of Progress." Past \& Present 178:210-242.

Smith, Roger. 2011. “The Sixth Sense': Towards a History of Muscular Sensation." Gesnerus 68: 218-271.

Smith, Roger. 2013. Free Will and the Human Sciences in Britain, 1870-1910. London: Pickering and Chatto. Swazey, Judith P. 1969. Reflexes and Motor Integration: Sherrington's Concept of Integrative Action. Cambridge: Harvard University Press.

Turner, R. Stephen. 1994. In The Eye's Mind: Vision and the Helmholtz-Hering Controversy. Princeton: Princeton University Press.

Tortajada, Maria. 2011. “Technique/Discourse: When Bergson Invented His Cinematograph.” Semiotic Inquiry 31:131-151.

Valentine, Elizabeth R. 1999. "The Founding of the Psychological Laboratory, University College London: 'Dear Galton... Yours truly, J. Sully'.' History of Psychology 2:204-218.

Valentine, Elizabeth R. 2012. "Spooks and Spoofs: Relations Between Psychical Research and Academic Psychology in Britain in the Inter-War Period." History of the Human Sciences 25:69-90.

The Virtual Laboratory: Essays and Resources on the Experimentalization of Life. Ver 1.0. c.2001. Max Planck Institut für Wissengeschaftsgeschichte. http://vlp.mpiwg-berlin.mpg.de/index_html (last accessed 28 October 2016).

Wade, Nicholas J. 2005. Perception and Illusion: Historical Perspectives. New York: Springer.

Wassmann, Claudia. 2009. "Physiological Optics, Cognition and Emotion: A Novel Look at the Early Work of Wilhelm Wundt." Journal of the History of Medicine and Allied Sciences 64:213-249.

Wassmann, Claudia. 2014. “'Picturesque Incisiveness': Explaining the Celebrity of James's Theory of Emotion." Journal of the History of the Behavioural Sciences 50:166-188.

Winter, Alison. "Screening Selves: Sciences of Memory and Identity on Film." History of Psychology 7:367401.

Young, Jacy L. "Test or Toy? Materiality and the Measure of Infant Intelligence." History of Psychology 18:103-118.

Young, Robert Maxwell. [1970] 1990. Mind, Brain and Adaptation in the Nineteenth Century: Cerebral Localization and its Biological Context from Gall to Ferrier. Oxford: University Press. 